
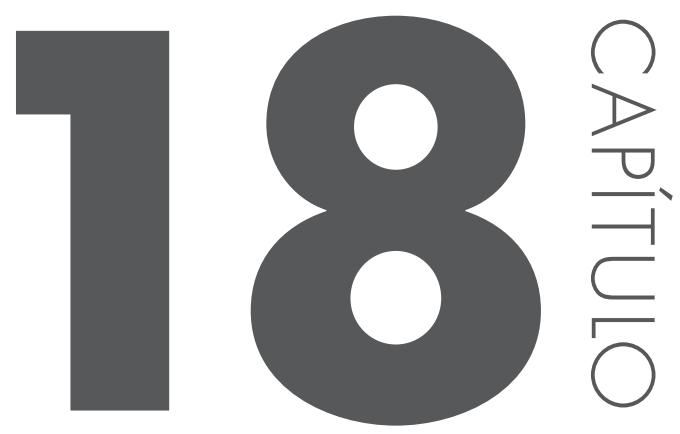

\title{
FISIOLOGIA DA BARREIRA EPITELIAL INTESTINAL
}

Francisco Adelvane de Paulo Rodrigues

Pedro Henrique Quintela Soares de Medeiros

Mara de Moura Gondim Prata

Aldo Ângelo Moreira Lima 


\subsection{PRIMEIROS RELATOS SOBRE A FUNÇÃO DE BARREIRA INTESTINAL: TRANSPORTES CELULARES NO INTESTINO}

A busca sobre o entendimento e a classificação do funcionamento das células intestinais é algo constante e não recente. Os primeiros reportes sobre a existência de uma configuração celular, a qual propiciava funções especializadas, tal como a função de barreira morfofuncional intestinal é encontrada na literatura médica ao final do século XIX. Subsequentemente, na primeira metade do século XX, essa função foi extensivamente estudada por técnicas associadas à investigação do transporte iônico.

Nossa compreensão atual de como as moléculas atravessam seletivamente os epitélios, decorre dos trabalhos pioneiros de Hans Ussing e colaboradores, iniciados em 1940. Este cientista dinamarquês investigou a temática do transporte iônico, descrevendo nessa época os mecanismos pelo quais os íons eram ativamente transportados em epitélio de anfíbios. Além disso, Ussing e Zerahn desenvolveram o método in vitro denominado de Câmaras de Ussing e, desde então, essa técnica passou a ser amplamente utilizada para estudar o transporte iônico, absorção, transporte de substratos e de fármacos, assim como transporte celular em respostas a estímulos imunológicos e a patobiológicos.

Outro avanço sobre o assunto foram as primeiras visualizações em nível de ultraestrutura, em 1963, por Farquhar e Palade, das junções firmes ou Tight junctions (TJs) do inglês, que são componentes proteicos formadores da via paracelular. Os dois propuseram pela primeira vez a existência de uma complexa junção apical entre as células intestinais e que ela se dividia em regiões morfologicamente distintas.

$\mathrm{Na}$ mesma temática, estudos mais recentes do grupo de Shoichiro Tsukita e Sachiko Tsukita, na Universidade de Kyoto, utilizando técnicas moleculares refinadas, contribuíram significativamente, para o melhor entendimento do funcionamento da via paracelular e da função de barreira exercida pelo epitélio intestinal. Estes cientistas foram os primeiros a demonstrar, em 1998, a existência de proteínas denominadas de claudinas (Claudina-1 e 2), nome que vem da palavra do latim claudere ("para fechar"), localizadas nas junções firmes da via paracelular. Atualmente, essas proteínas são tidas como as principais reguladoras das junções firmes e da permeabilidade intestinal. Com a caracterização do complexo de proteínas formadoras das TJ por Tusukita e colaboradores, a sociedade cientifica procura investigar a contribuição dessas proteínas e junções para as patobiologias que afetam o trato gastrintestinal (TGI), como também suas correlações com as comorbidades e doenças crônicasdegenerativas, tais como a enteropatia ambiental, malnutrição, diabetes, síndrome metabólica dentre outras. Neste contexto, 
este capítulo traz uma abordagem atualizada, sobre os componentes estruturais e funcionais, regulação, imunomodulação e biomarcadores da barreira morfofuncional do epitélio intestinal.

\subsection{MORFOLOGIA DA BARREIRA INTESTINAL}

Os elementos que formam a função de barreira do epitélio intestinal podem ser classificados, conforme a sua localização e função, em componentes extracelulares e celulares.

\subsubsection{COMPONENTES EXTRACELULARES}

A primeira linha de defesa no trato gastrointestinal é encontrada no lúmen intestinal de forma não específica. A ação do pH gástrico e das secreções pancreáticas e biliares de enzimas digestivas que se localizam neste espaço, tais como as lipases, proteases, amilases e nucleases, ajudam na digestão e exercem efeitos catalíticos e tóxicos sobre microrganismos e antígenos.

Em adição, a superfície da mucosa intestinal é coberta por uma camada de mucinas e lipídios que limitam a exposição da monocamada das células epiteliais intestinais da ação e do trauma físico de partículas dentro do lúmen, como também impedem o contato direto do epitélio a microrganismos.

A camada de muco possui propriedades hidrofóbicas e surfactantes. Esta camada contribui para a retenção das secreções da mucosa que são ricas em peptídeos antibacterianos e imunoglobulina A. O muco fornece proteção contra os microrganismos luminais, como as bactérias, destruindo-as e prevenindo a sua adesão à mucosa e ao epitélio intestinal.

Além disso, o peristaltismo intestinal, em conjunto com a secreção de água em massa em resposta a um estímulo patogênico, também são fatores essenciais que ajudam na função de proteção da barreira intestinal.

\subsubsection{COMPONENTES CELULARES: CARACTERÍSTICAS MORFOLÓGICAS}

Morfologicamente, uma das principais características do intestino é a existência de vilosidades e de criptas em sua arquitetura. As vilosidades se estendem para o lúmen intestinal e são revestidas por uma só camada de epitélio colunar que contém células terminalmente diferenciadas. As criptas são invaginações epiteliais na mucosa do intestino, responsáveis pelo potencial proliferativo deste tecido. Ambas as regiões (criptas e vilos), possuem uma especificidade em relação às células e suas funções.

Nas criptas, residem as células-tronco intestinais (CTI), que possuem duas propriedades funcionais: a capacidade de se perpetuar ao longo de um período 
prolongado (autorrenovação) e a capacidade de gerar todas as células diferenciadas do tecido de origem (multipotência). Assim, são responsáveis por promover a constante renovação da população celular do epitélio intestinal.

As CTIs se renovam ao longo da vida e produzem um tipo especial de células denominadas como progenitoras ou transitórias, as quais preenchem o restante das criptas. As células transitórias têm uma capacidade de autorrenovação muito limitada, ocorrendo diferenciação da sua prole em linhagens de células maduras após três a quatro divisões celulares.

Conforme as células migram das criptas, movendo-se na direção apical, vão diferenciando-se em enterócitos absortivos ou em qualquer um dos três tipos de células secretórias: células caliciformes, células de Paneth ou células enteroendócrinas. Esse processo é acompanhado por uma redução do ritmo proliferativo e apoptose no ápice da vilosidade.

As células absortivas, conhecidas ainda como células colunares, são as mais abundantes entre os tipos celulares. Essas células apresentam borda em escova, caracterizada por uma densa matriz de vilosidades em sua superfície apical. As células caliciformes assumem a morfologia permanente de um cálice, pela contínua produção e acúmulo temporário de vesículas de secreção glicoproteica, compostas principalmente de mucina, na região apical. Localizam-se distribuídas entre as células absortivas (enterócitos). Por produzirem grande quantidade de muco, têm como função lubrificar e proteger o epitélio intestinal.

As mucinas adicionam uma barreira física no epitélio intestinal, ajudando a conter bactérias comensais no lúmen do intestino, impedindo a sua adesão nas células epiteliais.

As células de Paneth diferem dos outros tipos de células diferenciadas, uma vez que se encontram dispersas na parte inferior da cripta, não seguindo o percurso migratório ascendente. Elas são responsáveis por secretar proteínas antibacterianas que impedem ainda mais o acesso direto dos microrganismos à mucosa intestinal, agindo assim como reguladoras da densidade microbiana e protetoras de células-tronco próximas. As menos abundantes, as células enteroendócrinas (de que existem muitos subtipos), são menores e secretam vários hormônios intestinais, dentre os quais peptídeos e catecolaminas.

\subsection{JUNÇÕES FIRMES}

As junções firmes são estruturas complexas e dinâmicas, que incluem uma série de proteínas juncionais capazes de cruzar a bicamada lipídica celular e se ligarem à porção extracelular na célula adjacente.

Funcionalmente, as junções firmes ou oclusivas regulam a passagem paracelular de íons, solutos e água. Elas exercem função de barreira semipermeável entre 
o domínio apical e basolateral, mantendo a polaridade celular e bloqueando a livre difusão de proteínas, lipídeos, produtos patogênicos, dentre outros.

Em nível molecular, as junções firmes são constituídas por três grupos de proteínas integrais de membrana- claudinas, ocludinas e moléculas de adesão juncional- além de um número considerável de outras proteínas citoplasmáticas acessórias, as quais incluem as zonula occluden ( $\mathrm{ZO})$, cingulina e outras proteínas guanilato-quinase associadas à membrana.

As proteínas transmembranares medeiam às adesões celulares e vedam os espaços, podendo ser divididas conforme a quantidade de alças que cruzam a membrana plasmática. As ocludinas, a família de claudinas e a tricellulina são proteínas que contêm quatro alças transmembranares e duas extracelulares, com os terminais $\mathrm{N}$ e $\mathrm{C}$ citoplasmático. As proteínas citoplasmáticas acessórias ZOs, subdividem-se em ZO-1, ZO-2 e ZO-3 e conectam as proteínas transmembrenares ao citoesqueleto de actina. Esta interação é necessária para a manutenção da integridade estrutural da função de barreira do epitélio intestinal (Figura 18.1)

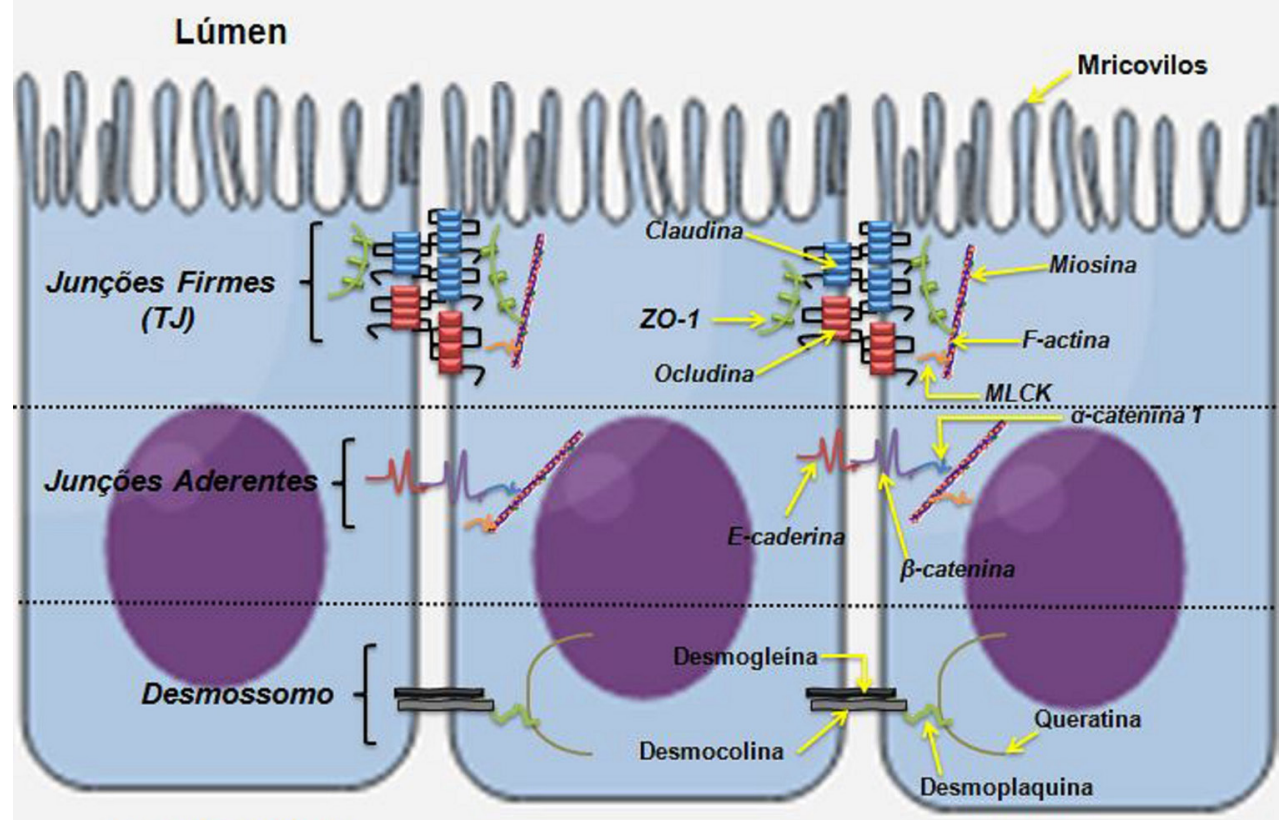

Lâmina própria

Figura 18.1 - Logo abaixo da base da microvilosidades, as membranas plasmáticas das células adjacentes são fundidas por meio das junçōes firmes. As proteínas formadoras dessas junçōes são claudinas, ocludina e Z0-1, que interagem com os milamentos do citoesqueleto (F-actina e Miosina). Mais abaixo se encontram as proteínas das Junçōes aderentes: E-caderina, $\alpha$-catenina l, $\beta$-catenina, $\delta 1$ catenina (também conhecido como PI20 catenina; não mostrado) que interagem comr F-actina. A MLCK está associada com 0 anel de actomiosina perijunctional. Desmossomos, que estão localizados abaixo do complexo juncional apical é formado por interações entre desmogleína, desmocolina, desmoplaquina e filamentos de queratina. MLCK (Myosin light-chain kinase, do inglês). 
A regulação da manutenção das junções firmes é influenciada por vários estímulos fisiológicos e fisiopatológicos. Esta regulação complexa envolve diversas vias de sinalização, incluindo a proteína quinase $\mathrm{C}(\mathrm{PKC})$, proteínas quinases ativadas por mitógenos (MAPK), miosina quinase de cadeia leve (MLCK) e família Rho de pequenas GTPases. Detalharemos a seguir a participação de cada componente molecular para a manutenção da função paracelular no epitélio do TGI.

\subsubsection{OCLUDINA}

A ocludina foi à primeira proteína integral de membrana a ser identificada nas junções firmes de células epiteliais, em 1993. Seu nome vem do latim “occludere" que significa passagem restrita. A ocludina é uma fosfoproteína tetraspanina de $65 \mathrm{kDa}$ de membrana, com quatro domínios transmembranares, duas alças voltadas para o meio extracelular e uma alça para o espaço intracelular. Possui um N-terminal curto e um longo domínio C-terminal citoplasmático. A interação homofílica das alças extracelulares de ocludina com as células adjacentes parece criar uma barreira para macromoléculas, mas não contra os pequenos íons. O domínio C-terminal longo interage com várias proteínas intracelulares das junções firmes, como as ZOs, que são necessárias para a ligação de ocludina ao citoesqueleto de actina.

\subsubsection{CLAUDINAS}

As claudinas fazem parte de uma família multigênica, composta de pelo menos 27 membros. Suas isoformas mostram um padrão de expressão diferente, importantes para determinar as propriedades fisiológicas das junções firmes. Semelhante à ocludina, as claudinas são proteínas de 20-27 Da e, morfologicamente, possuem alça intracelular e duas extracelulares, além de domínios C-terminal e N-terminal citoplasmáticos. As alças extracelulares das claudinas fazem as interações homofílicas e heterofílicas com células adjacentes.

Essas interações criam tanto uma barreira, como poros seletivos para a passagem de determinadas moléculas pela via paracelular. Mesmo na ausência de outras proteínas de membranas (p. ex. ocludina), as claudinas são capazes de manter a função de barreira de forma independente e, por ter essa atribuição, é considerada a espinha dorsal e fundamental para manter a permeabilidade intestinal. Recentemente tem se atribuído às claudinas 2 e 15, função primordial para absorção intestina. Essas duas proteínas são formadoras de poros e expressadas em todas as regiões do intestino (Figura 18.2).

Trabalhos utilizando camundongos geneticamente modificados vêm caracterizando melhor a importância dessa família de proteína. Animais com 
deficiência de claudina-1 morrem dentro de 24 horas após o nascimento devido a uma perda severa de fluidos e eletrólitos através das junções prejudicadas.

As claudinas executam funções diferentes e podem ser divididas em dois tipos: aquelas que estão envolvidas na formação de barreira (diminuição da permeabilidade paracelular) e as que desempenham um papel na formação de poros ou canal (aumento da permeabilidade paracelular). É conhecido o efeito que claudina-1, $-3,-4,-5,-8,-9,-11$, e -14 podem ser categorizadas como claudinas formadoras de barreira, enquanto claudina-2, -7, -12, e -15 são claudinas formadoras de poros (Figura 18.2).

As propriedades funcionais de cada claudina dependem dos números e posições de aminoácidos carregados na primeira alça extracelular da molécula. Por exemplo, a distribuição e orientação de resíduos carregados negativamente na alça extracelular trabalham para repelir os íons carregados negativamente (ânions) e favorecem os íons carregados positivamente (cátions). As isoformas claudina-2 e -12, formadoras de poros, têm três (posições 53, 65 e 75) e quatro (posições 62, 66, 71 e 74) aminoácidos respectivamente, carregados negativamente nesta alça e devido a isso formam poros seletivos para cátions.

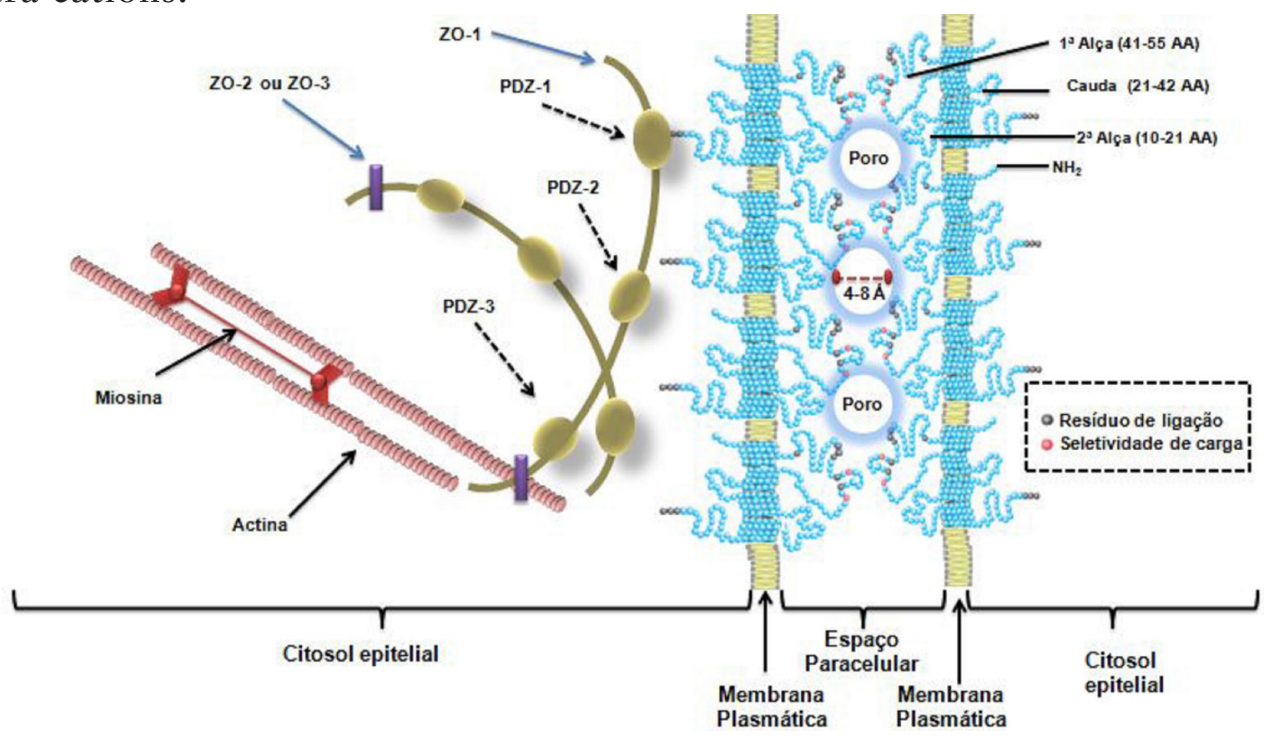

Figura 18.2 - Modelo de poros formados por claudinas. As claudinas (em azul) se ligam ao domínios PDZ-I das proteínas Z0-1. Por veZ, a proteína Z0-1 se liga aos filamentos de actina do citoesqueleto. 0 complexo de interções moleculares propricia a uma via seletividade para a permeação e a função de barreira funcional intestinal para moléculas que possuam tamanho de 4-8 Å. AA: Aminoácido. 
Evidencia-se o fato de que as claudinas formadoras de poros exercem papel ímpar para a permeação de $\mathrm{Na}^{+}$e, nesse sentido, contribuem para manter a absorção adequada nas células intestinais. Recentemente, foi demonstrado que a interação de claudina-2 e -15 , predominantemente localizada no intestino, é essencial para a homeostase da absorção de solutos e nutrientes pelas vias paracelular e transcelular. Animais geneticamente modificados para essas duas proteínas desenvolvem severas alterações no funcionamento das células intestinais, ocorrendo falha absortiva e mortalidade considerável.

\subsubsection{ZONULA OCLUDENS}

As proteínas Zonula Occludens (ZOs) fazem parte de um subgrupo de proteínas que também constituem as junções firmes. Já foram identificadas três proteínas ZOs: ZO-1 (220 Da), -2 (160 Da), e -3 (130 Da). Elas são proteínas com vários domínios de suporte, chamados domínios PDZ (PDZ-1, PDZ-2 e PDZ-3), um domínio Src homologia-3 (SH3), e um domínio-membrana associado à guanilato kinase (GUK) no lado do N-terminal. O PDZ é um domínio estrutural comum de 80-90 aminoácidos encontrados nas proteínas de sinalização. Desta forma, as proteínas contendo domínios PDZ exercem um papel importante na ancoragem de proteínas receptoras em membranas plasmáticas aos componentes do citoesqueleto (Figura 18.1 e 18.2). A terminologia PDZ é oriunda da combinação das primeiras letras de três proteínas: post synaptic density protein (PSD95), Drosophila disc large tumor suppressor (Dlg1), e ZO-1, nas quais ocorreram as primeiras descobertas e o compartilhamento do domínio.

Essas estruturas com vários domínios fornecem uma base intracelular necessária para a regulação e manutenção da estrutura junções firme. Por exemplo, claudinas se ligam aos primeiros domínios PDZ de ZO-1, -2, -3. Molécula de adesão juncional A (MAJ-A, ver adiante) se liga ao domínio de PDZ-3 de ZO-1 e ocludina se liga ao domínio GUK de ZO-1. O segundo domínio PDZ é utilizado para interações entre proteínas ZO.

Curiosamente, células deficientes de ZO-1 ainda são capazes de manter estruturas de junções firmes normais e mostram permeabilidade normal; no entanto, um atraso evidente na organização de outras proteínas de junções firmes, tais como ocludina e claudinas, é observado, indicando que as proteínas ZOs têm um papel importante na regulação desse conjunto de proteínas. Até o momento, têm sido feitos esforços para esclarecer o papel funcional de proteínas ZOs e estudos moleculares poderão elucidar melhor o papel dessas proteínas. 


\subsubsection{MOLÉCULA DE ADESÃO JUNCIONAL, JUNÇÕES ADERENTES E DESMOSSOMO}

As moléculas de adesão juncional (MAJs) são de proteínas transmembranares que estão envolvidas na formação das junções firmes junto com ocludinas e claudinas. A família MAJ pertence à superfamília das imunoglobulinas (Ig), caracterizada por dois domínios Ig extracelulares, um domínio transmembranar e um domínio C-terminal intracelular. Já foram identificadas várias proteínas dessa família, dentre elas MAJ-A, -B -C, MAJ-4, o receptor "coxsackie" e adenovírus (CAR) e molécula endotelial de adesão seletiva (ESAM). Os membros da MAJ são expressos em vários tipos de células epiteliais, incluindo as endoteliais e células do sistema imunológico, e exibem distintos padrões de expressão; no entanto, em células epiteliais intestinais, MAJ-A, MAJ-4 e CAR são expressas e envolvidas na regulação junções firmes.

Estudos in vitro e in vivo demonstram que a MAJ-A participa de forma importante da regulação e manutenção da função de barreira. A ausência de MAJ-A exibe em animais uma maior permeabilidade a dextrana, um marcador de permeabilidade intestinal e uma maior atividade de mieloperoxidase no cólon. Já o CAR, co-localizado por interação heterofílica com ZO-1 em células intestinais, parece limitar a invasão do vírus coxsackie e adenovírus.

As junções aderentes e desmossomos compõem o restante dos componentes do complexo paracelular. Junções aderentes são compostas de caderinas, formando imediatamente as junções firmes. A perda de junções aderentes resulta na disrupção da polarização epitelial, diferenciação e apoptose precoce das células epiteliais intestinais (Figura 18.2).

Os desmossomos formam estruturas que se conectam aos filamentos intermediários do citoesqueleto, proporcionando fortes ligações adesivas que mantêm a proximidade celular e são também locais de comunicações intercelulares. Recentemente, uma nova proteína humana conhecida como zonulina foi identificada como moduladora diretamente da permeabilidade intestinal. Expressão da zonulina de cadeia simples conduz à ativação de moléculas de sinalização, tais como o receptor de fator de crescimento epidérmico (EGR) e receptor ativado por proteinase 2 (PAR-2), o que resulta no aumento da permeabilidade. 


\subsection{FISIOLOGIA DA BARREIRA FUNCIONAL INTESTINAL}

\subsubsection{PRINCIPIO DO TRANSPORTE EPITELIAL DE NUTRIENTES, ÍONS E ÁGUA}

O transporte epitelial deve ser regulado de modo a atender as necessidades homeostáticas da célula, conforme o tipo de epitélio. Essa regulação envolve mecanismos autorregulados e coordenados. As células epiteliais estão dispostas em folhetos e formam monocamadas altamente polarizadas e apertadas que limitam os espaços luminais dos espaços intracelulares.

As propriedades eletroquímicas do epitélio do TGI permitem a absorção e o movimento de nutrientes, íons e ocorrem por meio de processos altamente coordenados, como também proporcionam barreira física contra a permeação de agentes patogênicos, toxinas, antígenos e moléculas pró-inflamatórias, do lúmen intestinal para o espaço basolateral.

As células epiteliais localizadas nos enterócitos intestinais criam esse mecanismo de permeabilidade seletiva por duas vias: o transporte transcelular e o transporte paracelular. A base dos transportes celulares no epitélio intestinal ocorre pela ação de proteínas transportadoras. Nesse sentido, o transporte ativo e a difusão facilitada são os principais mecanismos responsáveis pela absorção dos micronutrientes no intestino e essa capacidade é mantida pela influência de estímulos neurais, humorais e hormonais.

\subsubsection{TRANSPORTE TRANSCELULAR DE NUTRIENTES, ÍONS E ÁGUA}

A via de transporte transcelular no intestino está envolvida na absorção e no transporte de nutrientes, incluindo glicose, aminoácidos, peptídeos, ácidos graxos, minerais e vitaminas. Como a membrana celular é impermeável, esse processo é mediado predominantemente por transportadores ou canais específicos localizados nas membranas apicais e basolateral (Figura 18.3).

A glicose é um soluto essencial para o metabolismo celular. Sua absorção no intestino ocorre por meio de transporte transcelular em dois estágios, inicialmente por meio da passagem através da membrana apical e seguidamente pela basolateral dos enterócitos absortivos. O transportador de glicose sodiodependente (SGLT-1) é o responsável pela absorção de glicose na membrana apical por meio de transporte ativo secundário, utilizando o gradiente de $\mathrm{Na}^{+}$. O SGLT-1 possui uma região de ligação ao $\mathrm{Na}^{+}$e, após a sua ligação, permite o acesso da glicose ao receptor. São necessárias duas unidades de $\mathrm{Na}^{+}$para cada molécula de glicose, ambos transportados no mesmo sentido (lúmem- basolateral). 
Após a passagem por SGLT-1, a concentração aumentada de glicose no meio intracelular estimula a sua passagem por difusão facilitada por via da membrana basolateral pelo transportador de glicose GLUT2. Esse transportador atua independe da presença de $\mathrm{Na}^{+}$, possui elevada capacidade de transportar glicose, embora tenha baixa afinidade, com Km para a glicose $>50 \mathrm{mM}$, ou seja, é necessário que existam concentrações superiores a $50 \mathrm{mM}$ de glicose no meio intracelular para que a velocidade de transporte seja a metade da velocidade máxima (Figura 18.3).

A frutose, em contrapartida, é transportada através da membrana apical pelo GLUT-5; no entanto, pelo fato de este transporte não ser acoplado ao de $\mathrm{Na}^{+}$, sua entrada é relativamente ineficiente e pode, com facilidade, ser interrompida se forem ingeridas grandes quantidades de alimentos contendo esse açúcar. $\mathrm{O}$ mecanismo basolateral da absorção de frutose ainda não é bem compreendido.

As proteínas também são absorvidas via transporte transcelular. As enzimas digestivas (enteropeptidase e pepsina) reduzem a ingesta proteica a $40 \%$ de aminoácidos livres e a $60 \%$ de pequenos peptídeos (dois a seis aminoácidos). Estes são absorvidos pelos enterócitos. Em geral os transportadores de aminoácidos têm especificidade razoavelmente ampla, transportam possíveis subgrupos de aminoácidos (p. ex: neutros, aniônico e catiônico), no entanto, ocorre alguma sobreposição de sua afinidade para aminoácidos particulares. Além disso, alguns transportadores de aminoácidos, mas não todos, transportam seus aminoácidos, por um simporte em conjunto com a absorção obrigatória de $\mathrm{Na}^{+}$. 


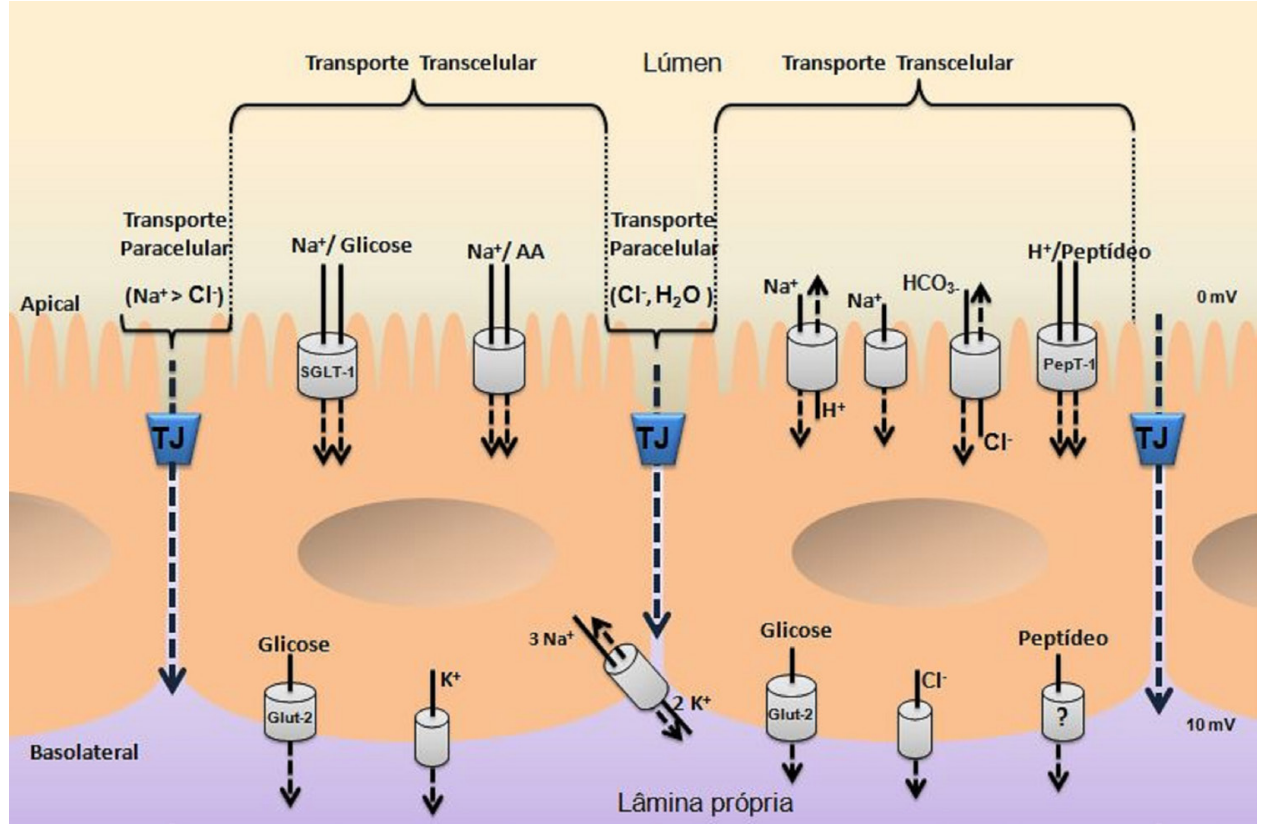

Figura 18.3 - Transportes nos enterócitos intestinais. Transporte transcelular e paracelular para íns, aminoácidos e substratos é mantido por proteínas e canais especializados. 0 gradiente eletroquímico de $\mathrm{Na}+$ fornece condições para absorção adequada de considerável quantidade das moléculas pela via transcelular. As proteínas que formam as junçōes firmes direcionam seletivamente uma via paracelular para $\mathrm{Na}+$, $\mathrm{Cl}$ - água. TJ: Tight Junctions.

O transportador primário e o responsável pela absorção de peptídeos é o peptídeo transportador 1 (PepT-1), um simportador que carrega peptídeos em conjunto com prótons. Os peptídeos absorvidos pelos enterócitos e imediatamente hidrolisados por uma série de peptidases citosólicas em seus aminoácidos constituintes. Os aminoácidos considerados não essenciais pelos enterócitos são exportados através da membrana basolateral e entram nos capilares sanguíneos para serem transportados para o fígado através da veia porta. O PepT-1 é de interesse clínico porque pode mediar a absorção dos fármacos, chamados fármacos peptidomiméticos, que incluem diversos antibióticos, bem como os agentes quimioterápicos. O mecanismo pelo qual os aminoácidos e os fármacos peptidomiméticos saem dos enterócitos não está completamente esclarecido, mas se presume que envolva proteínas transportadoras adicionais.

$\mathrm{O} \mathrm{Na} \mathrm{Na}^{+}$um íon por demais importante para a via transcelular. Resumidamente, a absorção de $\mathrm{Na}^{+}$ocorre por meio de mecanismos situados na membrana apical das células em borda em escova, todos impulsionados pelo potencial eletroquímico deste íon. Os valores de potencial eletroquímico favorecem o influxo de $\mathrm{Na}^{+}$por quatro mecanismos distintos: o primeiro mecanismo é de uma difusão via canal seletivo de $\mathrm{Na}^{+}$. O segundo mecanismo é constituído pelas várias proteínas 
de membrana que medeiam os cotransportes de substratos, tais como aminoácidos, peptídeos e glicose. O terceiro mecanismo é constituído do co-transporte eletro-neutro $\mathrm{Na}^{+}-\mathrm{Cl}^{-}$e, por fim, o quarto mecanismo é exercido pelo co-transporte $\mathrm{Na}^{+}-\mathrm{H}^{+}$também eletroneutro da membrana apical das células dos vilos e nas membranas basolaterais das células dos vilos e criptas.

Além disso, durante o transporte iônico de $\mathrm{Na}^{+}$, o cloreto $\left(\mathrm{Cl}^{-}\right)$e o bicarbonato (HCO3 ${ }^{-}$) são transportados de forma contraria ao transporte de $\mathrm{Na}^{+}$, desta forma mantendo a neutralidade elétrica através do trocador cloreto-bicarbonato. O fluxo de água via paracelular vai seguindo o gradiente osmótico gerado passivamente pelo transporte transcelular de eletrólitos.

\subsubsection{TRANSPORTE PARACELULAR E PERMEABILIDADE INTESTINAL}

A função de barreira ou permeabilidade intestinal é um evento dinâmico e, funcionalmente, responde a vários estímulos fisiológicos, patológicos e farmacológicos. Em condições fisiológicas normais, o espaço paracelular deve formar rigorosa barreira seletiva e semipermeável. Esta seletividade é proporcionada pelas junções firmes e é formada por um complexo de multiproteínas (ver anteriormente) transmembranares, dentre elas ocludina, claudinas, molécula de adesão e proteínas acessórias ZOs.

O complexo de proteínas das junções firmes tem propriedades funcionais, estruturais e bioquímicas necessárias para a interação com as proteínas actina e miosina perijuncional apical e, com base nisso, regulam o ritmo da permeação de íons via paracelular. A função de barreira exige que as biomoléculas possuam características especificas em relação a tamanho e carga, de íons e solutos de baixo peso molecular, condições essas necessárias para permear pelo espaço paracelular. É conhecido o fato de que as junções firmes expressas na cripta são mais permeáveis às moléculas com raios maiores de $50 \AA$ A , enquanto junções apertadas nas vilosidades só permitem a passagem de moléculas que tenham tamanhos menores a $6 \AA$ de raios.

Os íons podem mover-se do lúmen para a lâmina própria e vice-versa por via paracelular. O movimento passivo de $\mathrm{Na}^{+}$entre os dois compartimentos é feito pela via paracelular, que tem na junção firme, um elemento regulador e, nos gradientes eletroquímicos e osmóticos, a energia determinadora do sentido de deslocamento. O fluxo paracelular é bidirecional e a limitação dos transportes nessa região é determinada pelas proteínas de junções firmes, principalmente.

A regulação da permeabilidade intestinal envolve diversas vias funcionais. Mudanças rápidas na permeabilidade ocorrem via atividade da quinase de cadeia leve da miosina (MLCK: Myosin light chain kinase, do inglês), contração do citoesqueleto e por endocitose de proteínas das junções firmes. Enquanto isso, os 
distúrbios de permeabilidade mais prolongados envolvem a modulação da transcrição de proteínas das junções firmes, a apoptose de células epiteliais e alterações estruturais no epitélio.

A MLCK é uma enzima calmodulina $\mathrm{Ca}^{++}$dependente que fosforila especificamente a cadeia leve da miosina (MLC) em resposta, tanto a estímulos fisiológicos, quanto a patológicos. A fosforilação da MLC resulta em contração do complexo actina-miosina e alteração conformacional do arranjo intracelular do citoesqueleto, e, assim, conduz a uma disfunção da barreira epitelial. Por exemplo, a atividade MLCK está envolvida na endocitose da ocludina em resposta a mediadores inflamatórios como o TNF (fator de necrose tumoral). É reportado que essa citocina induz especificamente a internalização de ocludina mediante a endocitose. Esse evento destaca o papel das vias de tráfego vesicular na regulação das junções firmes.

In vivo, a avaliação funcional da permeabilidade epitelial intestinal pode ser alcançada com a medição da permeabilidade diferencial da mucosa intestinal por meio de marcadores moleculares não absorvíveis, incluindo monossacarídeos e dissacarídeos, ao longo do eixo das vilosidades e criptas. Além disso, a propriedade fisiológica da via paracelular, também pode ser corretamente avaliada in vitro pela medição da resistência elétrica transepitelial e potenciais de difusão iônica, como também por via da quantificação do fluxo paracelular mediante moléculas marcadas e/ou de elétrons-densos de vários tamanhos. Por exemplo, o teste de permeabilidade intestinal por lactulose e manitol. Dois açucares não metabolizados que especificamente marcam a via paracelular e transcelular de barreira funcional intestinal.

Utilizando ambas as abordagens, alguns estudos demonstraram que a permeabilidade intestinal anormal é caracterizada por vários distúrbios inflamatórios crônicos, em que esse fenômeno é associado ao desaparecimento de proteínas estruturais essenciais, localizadas nas junções firmes no epitélio intestinal.

Animais geneticamente modificados e técnicas in vitro para avaliar a permeabilidade intestinal, mostraram que o transporte eficiente de glicose no intestino é dependente de junções firmes, em especial dependente de claudinas -2 e -15. A deficiência de claudina -15 favorece drasticamente para reduzir a absorção e, consequentemente, resulta em alterações da homeostase e no metabolismo desse substrato, comprometimento significativo na resistência transepitelial e na condutância iônica paracelular para $\mathrm{Na}^{+}$. Além disso, os padrões de expressão dessas proteínas e de suas funções variam, diferenciando-se entre a infância e a fase adulta. 
Estudo recente demonstrou por meio de um modelo mais avançado, utilizando duplo Knockout para claudina -2 e -15, que o fluxo paracelular de $\mathrm{Na}^{+}$ desde a submucosa intestinal é dependente dessas duas proteínas. Claudinas-2 e -15 , proteínas formadoras de poros, desempenham papel essencial para a manutenção dos níveis adequados de $\mathrm{Na}^{+}$luminal, que subsequentemente é necessário para a absorção adequada de glicose, aminoácidos e gorduras. $\mathrm{O}$ gradiente gerado para $\mathrm{Na}^{+}$proporciona condições necessárias para o funcionamento das funções eletrofisiológicas (resistência, condutância e permeabilidade) à barreira intestinal. Vale ressaltar que a perda de claudinas- 2 e -15 leva à morte na infância de camundongos transgênicos, como resultado da alteração no metabolismo absortivo iônico e má absorção de nutrientes (Figura 18.4).

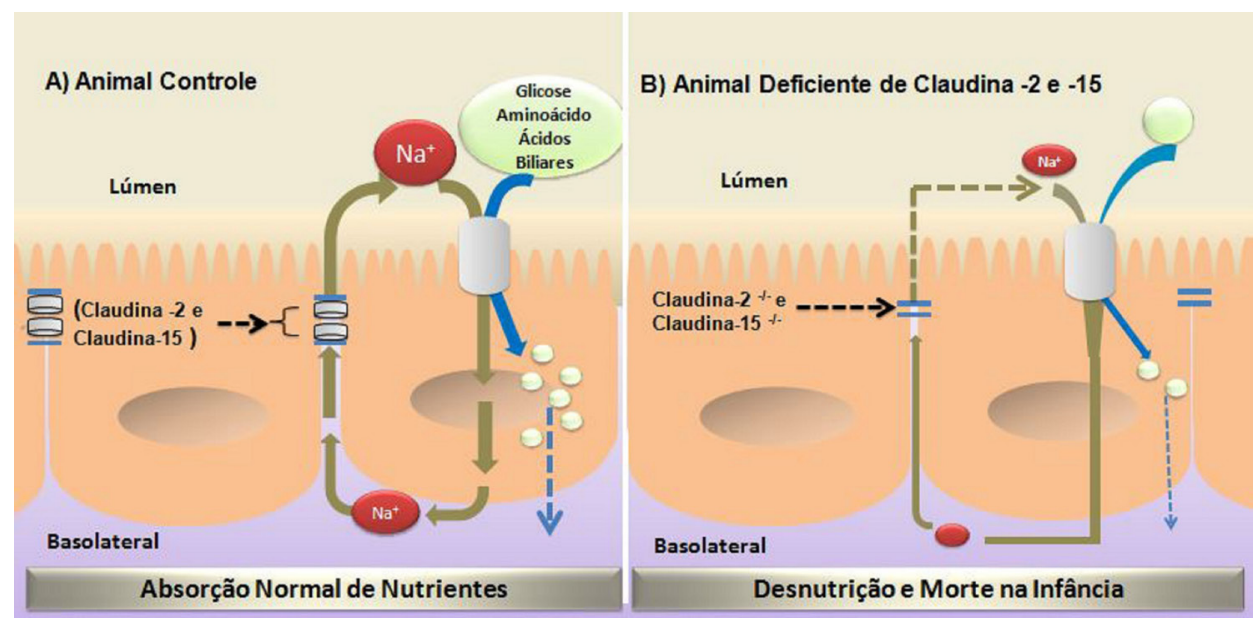

Figura 18.4 - Disrupç̃ão do transporte paracelular decorrente da deficiência de claudina -2 e - 15 em camundongos geneticamente modificados. Simultânea ausência de claudina -2 e -15 no espaço paracelular leva a falha na absorção dos principais nutrientes (glicose, aminoácidos e ácido graxos via ácido biliares) que depende de valores adequados de $\mathrm{Na}+$ luminais. A) Esquematização da absorção dos principais substratos em condição normal. B) Iransporte deficiente de $\mathrm{Na}+\mathrm{na}$ ausência de claudina -2 e - 15 resulta em comprometimento da absorção de glicose, aminoácido, e ácido biliares e subsequentemente morte durante a infância.

Resultados de estudo também recente com desnutrição animal demonstraram que essa condição modifica o perfil de transporte paracelular. O défice nutricional desencadeado por dieta multideficiente em proteína propicia eleveda transcrição nos níveis RNAm de claudina -2 e alteração na permeabilidade celular avaliada com marcador dextrana. 


\subsection{REGULAC̣ÃO DA BARREIRA FUNCIONAL INTESTINAL}

A manutenção da homeostase da barreira funcional intestinal é um processo co-regulado por mediadores: células epiteliais, células do sistema imune, microbiota e sistema nervoso entérico. Por motivos didáticos, este tópico abordará cada um destes componentes de forma fragmentada, porém é preciso compreender que a atuação destes fatores se dá de forma integrada e dinâmica. As Figuras 18.5 e 18.6 mostram estes componentes em conjunto, caracterizando, respectivamente, a representação histológica da anatomia da barreira e os mecanismos regulatórios da barreira.

\subsection{PAPEL DO EPITÉLIO INTESTINAL: FUNÇÕES ESPECIALIZADAS}

A capacidade de diferenciação das células epiteliais do intestino permite o desenvolvimento de um completo aparato celular capaz de impedir a invasão de substâncias no epitélio. Neste contexto, a primeira linha de defesa é formada pela ação de células especializadas secretoras. Estas células, células caliciformes e células de Paneth, produzem, respectivamente, mucinas glicosiladas e proteínas antimicrobianas, composição que permite uma barreira física e química.

A mais abundante das mucinas é a mucina do tipo 2 (MUC2), sendo essencialmente importante na superfície epitelial do cólon. Estudos em camundongos deficientes de MUC2 mostram desenvolvimento espontâneo de colite. Outros fatores produzidos pelas células de goblet e que também são importantes para a formação da barreira física do intestino junto ao muco são: fator de trevo 3 (TFF3) e molécula $\mathrm{B}$ semelhante à resistina (RELMB).

As proteínas antimicrobianas produzidas pelas células de Paneth são as defensinas, catecilidinas e lisozimas. Estas proteínas, juntamente com a proteína III $\gamma$ lectina do tipo $\mathrm{C}$ - produzida tanto pelas células de Paneth como pelas células epiteliais comuns, rompem estruturas bacterianas. Podem ter como alvo as membranas de superfície, no caso das defensinas e catecilidinas, ou a parede de peptideoglicanos de bactérias Gram-positivas, no caso das lectinas do tipo C.

Outra contribuição das células do epitélio para a proteção da barreira intestinal se dá no transporte da imunoglobulina IgA através do epitélio. A IgA é produzida por células plasmáticas na lâmina própria e tem papel importante na neutralização inespecífica de microorganismos.

Vale ressaltar o papel importante das células $\mathrm{M}$, células especializadas do epitélio que têm a propriedade de endocitose e transporte de antígenos para as células do sistema imune na lâmina própria. Estudos mais recentes mostram que estas células são capazes de mediar transportes específico e não-específico de antígenos microbianos e que tais processos também podem ser mediados pelas células caliciformes. 


\subsection{PAPEL DO SISTEMA IMUNE: ATIVAC̣ÃO DA INFLAMAÇÃO}

A influência do sistema imune no controle homeostático da barreira intestinal é de grande relevância. Ele permite que o organismo adquira tolerância a antígenos inofensivos (como antígenos da dieta ou microbiota residente no intestino) e simultaneamente seja capaz de desenvolver respostas contra patógenos. Este estado é também chamado de "inflamação fisiológica".

A primeira resposta imune a ser ativada é não-específica e pertence à imunidade inata, representada por células epiteliais e células do sistema imune localizadas na lâmina própria: células dendríticas, macrófagos e células NK ('natural killer'). Estas células reconhecem padrões moleculares associados a patógenos (PAMP - pathogen-associated molecular patterns) a partir de receptores de reconhecimento de padrões (PRRs - pattern recognition receptors), como receptores toll-like (TLRs - toll-like receptors) e receptores de domínio de oligomerização de ligação de nucleotídeos (NODs - nucleotide-binding oligomerization domain receptors). No epitélio intestinal em condições normais, os PRRs são ativados na porção apical por bactérias da microbiota residente, ajudando na secreção de substâncias antimicrobianas e na manutenção da tolerância. Quando há alteração na barreira do epitélio e entrada de bactérias, uma resposta pró-inflamatória é gerada pela ativação basolateral dos PRRs, bem como de PRRs de outras células do sistema imune inato, como as células dendríticas, que determinam o desenvolvimento das respostas celular e humoral pelo sistema imune adaptativo.

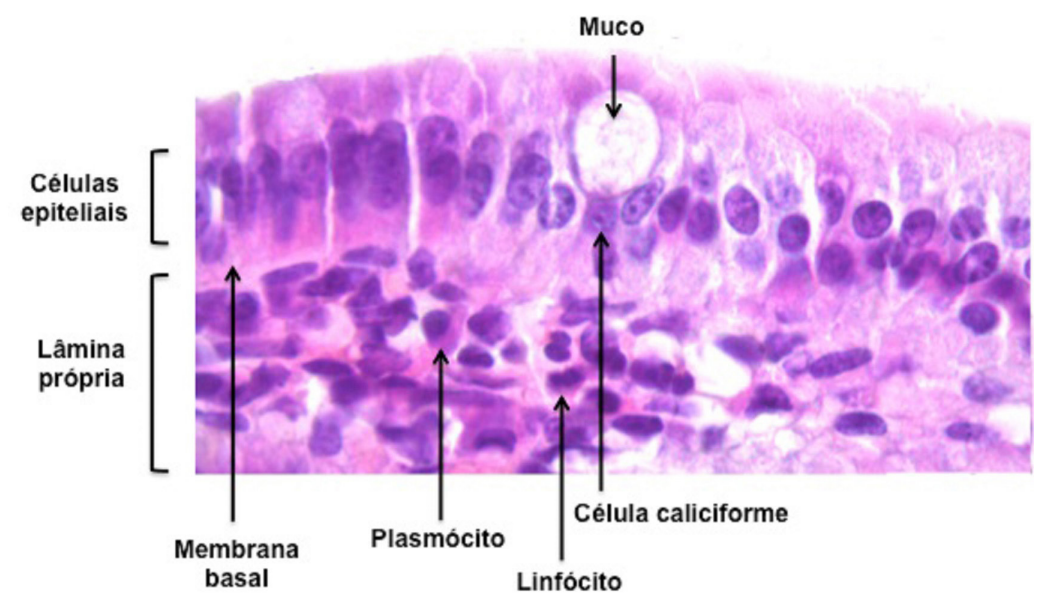

Figura 18.5 - Representação histológica dos componentes da barreira intestinal. A barreira intestinal é composta de uma camada simples de células epiteliais colunares, assim como pela camada mucóide e lâmina própria. As células caliciformes, que sintetizam e liberam mucina, assim como outras células especializadas, estão presentes. Mais externamente, a camada mucóide (que não pode ser visualizada histologicamente) é localizada imediatamente acima das células epiteliais. As junçōes firmes fecham 0 espaço paracelular entre as células epiteliais. A lâmina própria, localizada abaixo da membrana basal, contém várias células do sistema imune. 
A resposta adaptativa inclui linfócitos $\mathrm{T}$ e $\mathrm{B}$ com resposta específica e de memória para certos antígenos. Células T CD4+ localizam-se na lâmina própria, gerando células Th1 e Th17 com propriedades pró-inflamatórias. As células T regulatórias (Treg), expressando Foxp3, atuam contrabalanceando este efeito, ajudando a manter a inflamação sob controle.

A habilidade de citocinas, como TNF- $\alpha$ e IFN- $\gamma$, de regular a função das junções firmes já está bem descrita. Os efeitos de aumento de expressão de junções firmes, remoção vesicular de proteínas do complexo de junções firmes, degradação das junções firmes, ativação de quinase e modulação do citoesqueleto são todos eventos descritos como mediados por estas citocinas. É também sabido que o tratamento com anticorpos anti-TNF em doença de Crohn corrige a função da barreira intestinal. Nos mecanismos de lesão da barreira induzida por TNF- $\alpha$, é proposto que o aumento da expressão MLCK seja bastante presente, sendo um mecanismo comum de vários estímulos, como IL-1 $\beta$, lipopolissacarídeo, acetaldeído, infecções por Escherichia coli enteropatogênica, Helicobacter pylori e giardíase.

Outras células do sistema imune importantes para a homeostase da barreira intestinal são os macrófagos e as células dendríticas, fagócitos encontrados na lâmina própria. Elas atuam na manutenção da tolerância a antígenos da dieta e no controle de patógenos e microorganismos comensais.

\subsection{PAPEL DA MICROBIOTA: INTEGRAC̣ÃO COM SISTEMA IMUNE}

Há mais de $10^{14}$ tipos de bactérias residentes no trato gastrointestinal que estabelecem uma relação simbiótica com as células do organismo humano. Esse ecossistema é comumente denominado microbiota intestinal. Neste contexto, as células do epitélio intestinal, juntamente com as células do sistema imune, mantêm um mecanismo de imunorregulação complexo, tolerando a microbiota e desenvolvendo respostas contra patógenos.

A importância dos microorganismos residentes no intestino é verificada nos mais diversos níveis, passando desde a influência nas propriedades de proliferação, diferenciação e renovação celular do epitélio intestinal, até a modulação da permeabilidade intestinal, expressão de peptídeos antimicrobianos e camada de muco para a barreira físico-química.

A influência da microbiota nas propriedades de renovação celular foi mostrada em diversos estudos com animais criados em ambientes livres de microorganismos. Estes animais possuem morfologia intestinal danificada, com reduzido vilo ileal e menores criptas, além de diminuição da capacidade de renovação ce- 
lular. Tais efeitos parecem estar associados à ativação de receptores TLR e NOD, que induzem sinais de fortificação da barreira.

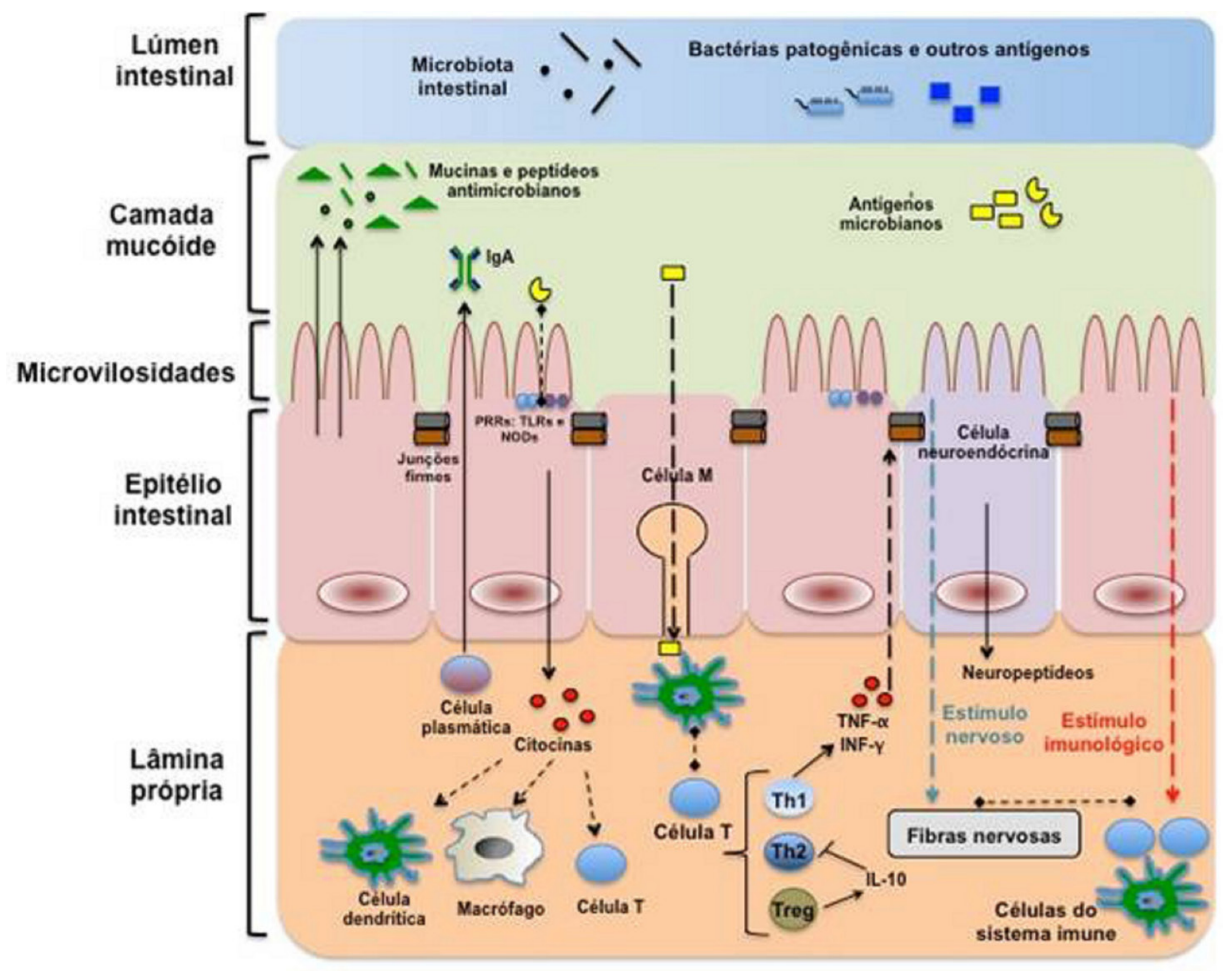

Figura 18.6 - Representacãão esquemática da regulação da barreira funcional intestinal. Diversos componentes atuam na manutenção da homeostase desta barreira. No lúmen intestinal, a microbiota residente tem papel protetor contra bactérias patogênicas, evitando a colonização e invasão no epitélio. A camada mucóide, com peptídeos antimicrobianos e mucinas, funciona como barreira para a penetração de antígenos microbianos. Tais substâncias são produzidas por células especializadas do epitélio intestinal, células caliciformes (mucina) e células de Paneth (peptídeos antimicrobianos). A lgA, presente também na camada mucóide é secretada por células plasmáticas na lâmina própria. A regulação imunológica da barreira se inicia com a ativacạ̃o por antígenos de receptores de reconhecimento de padrões (PRRs), receptores toll-like (TLRs) e receptores de domínio de oligomerização de ligação de nucleotídeos (NODs), que induzem a liberação de citocinas que podem ativar células do sistema imune localizadas na lâmina própria. Alternativamente, células do epitélio intestinal especializadas em endocitar e transportar antígenos para a lâmina própria (células M) podem atuar, havendo reconhecimento por células apresentadoras de antígenos (células dendríticas) para processamento e indução de células T, podendo gerar distintos perfis Thl, Th2 e Treg. 0 s mediadores inflamatórios liberados no processo (citocinas TNF- $\alpha$ e IFN- $\gamma$ ) podem modificar as funçōes das junçōes firmes, levando à distúrbios de permeabilidade intestinal. A complexa interação sistema nervoso-sistema imune também ocorre na barreira intestinal, com atuacão importante de células especializadas do epitélio, células neuroendócrinas, que podem secretar neuropeptídios reguladores da resposta imune. 
Em relação aos efeitos da microbiota na permeabilidade intestinal, a maioria dos estudos mostra que o uso de probióticos pode reverter o aumento da permeabilidade intestinal em diversos contextos, seja em modelos de lesão da barreira induzida por estresse, por deleção de genes de receptores TLR. Animais criados em ambientes estéreis também tem sua permeabilidade intestinal diferencialmente modulada por populações bacterianas. Estudos sugerem que uma microbiota mais diversa possa contribuir para manutenção da homeostase intestinal. Em modelo experimental de enteropatia ambiental em camundongos, a modulação da microbiota exacerbou os distúrbios na barreira intestinal, com aumento da permeabilidade intestinal e da expressão de claudina-2.

$\mathrm{O}$ reconhecimento da microbiota intestinal pelas células do sistema imune permite o desenvolvimento de funcionalidade da resposta imune. Estudos em animais livres de micróbios mostraram reduzida celularidade e prejudicada funcionalidade do sistema imune na lâmina própria do intestino delgado. Quando ocorre a disbiose da população microbiana residente no intestino, entretanto, bactérias podem ser transportadas para os linfonodos mesentéricos, levando ao desenvolvimento de resposta imune exacerbada anormal contra microorganismos. Além disso, certos componentes da microbiota são relacionados ao desenvolvimento de respostas inflamatórias, enquanto outros se relacionam a mecanismos anti-inflamatórios. A diversidade e composição da microbiota são fatores-chave para a manutenção da homeostase intestinal.

As evidências do papel da microbiota em doenças gastrointestinais indicam intensa associação, porém a exata cascata de mecanismos ainda não foi elucidada. É possível que o desequilíbrio da microbiota desencadeie a inflamação intestinal pela influência nos sinais de manutenção da barreira intestinal.

\section{8.9 PAPEL DO SISTEMA NERVOSO: INTEGRAC̣ÃO COM SISTEMA IMUNE}

A influência do sistema nervoso central na fisiologia intestinal inclui regulação da barreira intestinal, motilidade, secreção e fluxo sanguíneo. Esta interação SNC-intestino é também bidirecional, podendo a inflamação intestinal alterar mecanismos de nocicepção e outras doenças neurológicas.

O sistema nervoso entérico constitui uma rede de neurônios e células gliais que se distribuem em dois plexos principais: plexo mioentérico (ou plexo de Auerbach) e plexo submucoso (ou plexo de Meissner), estando em íntimo contato e comunicação com as células do epitélio intestinal, células do sistema imune e as células neuroendócrinas, colaborando para resposta do sistema imune a patógenos. Esta comunicação envolve a ação de neuropeptídios, neuro-hormônios, neurotransmissores, citocinas, quimiocinas, fatores de crescimento, dentre outras moléculas regulatórias. 
Sob condições fisiológicas ou patológicas, o sistema nervoso entérico regula a função da mucosa intestinal. Enquanto o plexo mioentérico regula principalmente a motilidade, o plexo submucoso, juntamente com as fibras nervosas na lâmina própria, é envolvido na regulação dos transportes epiteliais. Essas fibras têm íntimo contato com a lâmina basal, permitindo o reconhecimento de nutrientes absorvidos e antígenos, que podem agir na mudança das propriedades dos neurônios sensoriais e causar sensibilização periférica.

Um dos mecanismos mais estudados da sinalização neuroimune na fisiologia intestinal é ativação de mastócitos por fibras nervosas extrínsecas ou intrínsecas contendo hormônio liberador de corticotropina ou acetilcolina. Tal ativação induz a liberação de variados mediadores pelos mastócitos, como TNF- $\alpha$ e interleucinas, com efeitos nos transportes trans e paracelular do epitélio. Este distúrbio pode gerar ativação de resposta inflamatória exacerbada.

\subsection{DISTÚRBIOS ASSOCIADOS À BARREIRA FUNCIONAL INTESTINAL}

Várias evidências sugerem que a desregulação da função da barreira intestinal está associada à patogênese de várias doenças, como diabetes, doenças inflamatórias do intestino, doença celíaca, alergia a alimentos, esclerose múltipla e síndrome do intestino irritável. Os exatos mecanismos de causalidade, contudo, ainda não estão completamente elucidados.

Estudos em humanos e camundongos mostram que a alteração da permeabilidade intestinal não é condição suficiente para gerar doença. Além disso, a recuperação da barreira pode ocorrer, uma vez que o estímulo desapareça. Mecanismos regulatórios relacionados ao sistema imune parecem estar envolvidos neste processo. Em condições patológicas, entretanto, em que a capacidade regulatória é superada, há progressão do aumento da permeabilidade com potencial de aparecimento de doença intestinal inflamatória.

Pacientes com doença inflamatória do intestino denotam aumento da permeabilidade e alterações na expressão das junções firmes, caracterizados pela redução dos níveis de claudina-3, 4, 5 e 8 e ocludina, e aumento dos níveis de claudina-2 e ativação da quinase de cadeia leve de miosina. Essas mudanças na barreira são detectadas apenas em pacientes com doença ativa, sugerindo que tais distúrbios sejam consequências de uma resposta pró-inflamatória exacerbada com elevados níveis de IFN- $\gamma$ e TNF- $\alpha$, capazes de modular as junções firmes. Outro achado que concorre para o envolvimento de outros fatores, sejam genéticos ou ambientais, para o desenvolvimento da doença, é a associação de mutações em genes das proteínas NOD-2 e XBP1, relacionadas à reduzida produção de IL-10 ou inadequada tolerância a produtos microbianos.

A doença celíaca é uma condição autoimune de etiologia desconhecida que resulta da intolerância ao glúten, possuindo causas genéticas e ambientais. Não 
há consenso sobre a permeabilidade intestinal como causa da doença celíaca, sendo os estudos conflitantes. Em muitos casos, a permeabilidade intestinal alterada existe apenas em pacientes com a doença ativa, não ocorrendo na remissão da doença - remoção do glúten da dieta.

$\mathrm{O}$ aumento na permeabilidade intestinal é também relacionada a alergia a alimentos, sendo detectada mesmo na ausência dos alérgenos. Apesar de não ser colocada como a causa primária, os fatores ambientais (como infecção e estresse) aumentam a permeabilidade intestinal e a passagem de substâncias que, em condições normais, não passariam, colaborando para a resposta alérgica em indivíduos suscetíveis.

A síndrome do intestino irritável é uma desordem crônica funcional cujos mecanismos patofisiológicos continuam desconhecidos. Apesar dos subtipos clínicos variarem, todos os pacientes apresentam aumento na permeabilidade intestinal, com reduzidos níveis de $\mathrm{ZO}$ e ocludina, além de aumento dos níveis de claudina-2 e ativação da quinase de cadeia leve de miosina.

Outra condição clínica relevante e associada a distúrbios na barreira intestinal é a enteropatia ambiental, condição subclínica de alterações morfológicas e funcionais do intestino de indivíduos que vivem em ambientes com elevada contaminação ambiental. Alterações na permeabilidade intestinal em humanos e camundongos, além de modulação das junções firmes (aumento da expressão de claudina-2) em camundongos já foram relatadas na literatura.

Um dos modelos propostos para a indução de doenças inflamatórias baseados em alterações na função da barreira intestinal pressupõe a existência de um hospedeiro com sistema imune suscetível. O contato com um produto do ambiente externo neste organismo desencadeia uma resposta inflamatória exacerbada, levando ao desenvolvimento da doença. Segundo este modelo, os três componentes indispensáveis para o aparecimento de doenças são: 1) sistema imune geneticamente suscetível, 2) uma substância ambiental que desencadeia o processo patológico e 3) a habilidade desta substância de interagir com o sistema imune - permeabilidade intestinal.

Similarmente, alguns estudos inferem um mecanismo no qual o complexo das junções firmes integra uma relação de equilíbrio entre antígenos do lúmen e o sistema imune. Em um indivíduo saudável, aumentos regulados da permeabilidade intestinal levam ao desenvolvimento de resposta pró-inflamatória (com citocinas TNF- $\alpha$ e IFN- $\gamma$ ) balanceadas por respostas imunorregulatórias (com a citocina TGF- $\beta$ e ácido retinóico, que levam à diferenciação de células T regulatórias). A quebra deste equilíbrio, seja por fatores externos ou por suscetibilidade genética, leva a um aumento da resposta inflamatória e aumento da permeabilidade intestinal, levando a um estado de inflamação crônica potencialmente associada a um quadro patológico.

Outro mecanismo apontado como relevante para a doença é por via da zonulina. Muitas bactérias alteram o estado das junções firmes para satisfazer os próprios interesses. Vibrio chlolerae secreta uma variedade de toxinas e uma delas, a 
toxina zonula occludens, foi reconhecida como capaz de aumentar a permeabilidade intestinal com a ligação a um receptor da membrana apical do enterócito, com subsequente ativação de mecanismo intracelular, resultando em contração do anel actomiosina e elevada permeabilidade paracelular. Estudos posteriores descobriram o homólogo humano, nomeado zonulina. Sugere-se que, em várias condições de doença, um evento patofisiológico comum seja a expressão aumentada de zonulina da lâmina própria, com inadequada ativação desta via e subsequente aumento da permeabilidade paracelular.

Ainda não há estudos que mostrem uma relação direta de causalidade entre função da barreira intestinal e doenças inflamatórias, colaborando para a concepção multifatorial destas doenças. Além disso, melhor entendimento de como a microbiota intestinal modula a barreira ajudará a desenvolver alvos terapêuticos para prevenção ou tratamento de doenças gastrointestinais.

\subsection{MÉTODOS DE AVALIAC̣ÃO DE BARREIRA INTESTINAL}

Para avaliação da permeabilidade intestinal e suas doenças associadas, existe o uso de múltiplos testes e biomarcadores. Desses alguns apresentam uma correlação com a função da barreira intestinal, com o dano tecidual e ao grau de inflamação e resposta imune. (Tabela 18.1).

Tabela 18.1 - Marcadores intestinais associados a absorção, permeabilidade, danos e reparação intestinal, inflamação sistêmica e resposta imune.

\begin{tabular}{|c|c|c|c|c|}
\hline Biomarcadores & Tipo de amostra & Função & Patobiologia & Referências \\
\hline \multicolumn{5}{|c|}{ A absorção, permeabilidade, danos e reparação intestinal } \\
\hline $\begin{array}{l}\text { Taxa de lactulose/ } \\
\text { mannitol } \\
\text { (taxa de } \mathbf{L M} \text { ) }\end{array}$ & Urina & $\begin{array}{l}\text { A taxa LM é utilizada } \\
\text { para avaliar a área } \\
\text { de absorção, lesão e } \\
\text { reparação da barreira } \\
\text { funcional intestinal. }\end{array}$ & $\begin{array}{l}\text { A razão LM tem } \\
\text { mostrado ser um } \\
\text { teste sensivel para } \\
\text { avaliar alterações } \\
\text { na permeabilidade, } \\
\text { absorção e lesão da } \\
\text { barreira funcional } \\
\text { intestinal. }\end{array}$ & $\begin{array}{l}\text { Barbosa Jr. et } \\
\text { al., } 1999 \\
\text { Wang et al., } 2015\end{array}$ \\
\hline $\begin{array}{l}\text { \% Excreccão de } \\
\text { lactulose (\%L; } \\
\mathbf{3 4 2} \mathbf{~ D a )}\end{array}$ & Urina & $\begin{array}{l}\text { \% L mensura } \\
\text { o aumento da } \\
\text { permeabilidade } \\
\text { ou do dano do } \\
\text { epitélio intestinal. }\end{array}$ & $\begin{array}{l}\text { \%L está associada } \\
\text { com doenças } \\
\text { que alteram a } \\
\text { permeabilidade } \\
\text { e / ou lesão da } \\
\text { barreira funcional } \\
\text { gastrointestinal. }\end{array}$ & $\begin{array}{l}\text { Barbosa Jr. et } \\
\text { al., } 1999 \\
\text { Wang et al., } 2015\end{array}$ \\
\hline
\end{tabular}




\begin{tabular}{|c|c|c|c|c|}
\hline Biomarcadores & Tipo de amostra & Função & Patobiologia & Referências \\
\hline $\begin{array}{l}\text { \% Excrecção de } \\
\text { Mannitol (\%M; } \\
182 \text { Da) }\end{array}$ & Urina & $\begin{array}{l}\text { \%M mensura a área } \\
\text { de absorção intestinal. }\end{array}$ & $\begin{array}{l}\text { \%M está associada } \\
\text { com doenças que } \\
\text { alteram a área de } \\
\text { absorção do intestino. }\end{array}$ & $\begin{array}{l}\text { Barbosa Jr. et } \\
\text { al., } 1999 \\
\text { Wang et al., } 2015\end{array}$ \\
\hline $\begin{array}{l}\text { Proteína ligadora de } \\
\text { ácidos graxos do íleo } \\
(\mathbf{I - F A B P ;} \sim 13- \\
14 \text { kDa) }\end{array}$ & Plasma, soro, urina & $\begin{array}{l}\text { Localizado nas células } \\
\text { epiteliais do intestino } \\
\text { delgado e este é } \\
\text { importante para a } \\
\text { utilização, transporte } \\
\text { e metabolismo } \\
\text { de ácidos graxos. }\end{array}$ & $\begin{array}{l}\text { Esse é um marcador } \\
\text { bioquímico para } \\
\text { a célula intestinal } \\
\text { isquemicamente } \\
\text { danificado (baixo ou } \\
\text { ausência de l-FABP). }\end{array}$ & $\begin{array}{l}\text { Pelsers et al., } 2015 \\
\text { Wang et al., } 2015\end{array}$ \\
\hline $\begin{array}{l}\text { Diamina oxidase } \\
\text { (DA0; 91kDa) }\end{array}$ & Soro & $\begin{array}{l}\text { DAO expressa na } \\
\text { mucosa intestinal } \\
\text { e correlaciona-se } \\
\text { inversamente a } \\
\text { permeabilidade } \\
\text { intestinal. }\end{array}$ & $\begin{array}{l}\text { DAO relacionada } \\
\text { a integridade } \\
\text { da membrane e } \\
\text { maturidade celular } \\
\text { da mucosa do } \\
\text { intestine delgado }\end{array}$ & Wang et al., 2015 \\
\hline $\begin{array}{l}\text { Litostatine-l-beta } \\
(\operatorname{Reg} 1 \beta ; 19 \text { kDa })\end{array}$ & Fecal & $\begin{array}{l}\text { Essa proteína é } \\
\text { produzida em células } \\
\text { de criptas intestinais } \\
\text { e desempenha um } \\
\text { papel na reparação de } \\
\text { tecidos, crescimento e } \\
\text { proliferação de células. }\end{array}$ & $\begin{array}{l}\text { Detecção da proteína } \\
\text { presente nas fezes, } \\
\text { é um indicador } \\
\text { da proliferação de } \\
\text { células da cripta. }\end{array}$ & Peterson et al., 2013 \\
\hline \multicolumn{5}{|c|}{ Inflamação Intestinal } \\
\hline Leucócitos marcados & Fecal & $\begin{array}{l}\text { Leucócitos ligados } \\
\text { a radiomarcadores, } \\
\text { considerado o padrão } \\
\text { ouro para teste de } \\
\text { inflamação nas fezes }\end{array}$ & $\begin{array}{l}\text { Este indica o aumento } \\
\text { de mediadores } \\
\text { inflamatórios } \\
\text { no aumento da } \\
\text { permeabilidade } \\
\text { intestinal }\end{array}$ & $\begin{array}{l}\text { Turkay; Kasapoglu, } \\
2010\end{array}$ \\
\hline $\begin{array}{l}\text { Alfa-l-antitripsina } \\
(\alpha-1-A T ; 52 \text { kDa) }\end{array}$ & Fecal, Soro & $\begin{array}{l}\alpha \text {-l-AT é uma } \\
\text { glicoproteína, proteína } \\
\text { de fase aguda e é } \\
\text { inibidor de proteinase. }\end{array}$ & $\begin{array}{l}\text { A presença na amostra } \\
\text { fecal reflete um } \\
\text { aumento da } \\
\text { permeabilidade } \\
\text { intestinal durante } 0 \\
\text { processo inflamatório. }\end{array}$ & $\begin{array}{l}\text { Kosek et al., } 2013 \\
\text { Turkay; Kasapoglu, } \\
2010\end{array}$ \\
\hline
\end{tabular}




\begin{tabular}{|c|c|c|c|c|}
\hline Biomarcadores & Tipo de amostra & Função & Patobiologia & Referências \\
\hline $\begin{array}{l}\text { alfa2-macroglobulina } \\
(\alpha \mathbf{2 M}, \mathbf{8 2 0 k D a})\end{array}$ & Fecal, Soro & $\begin{array}{l}\text { É uma glicoproteínaa } \\
\text { que age anti- } \\
\text { proteinase, capaz } \\
\text { de inativar uma } \\
\text { grande variedade } \\
\text { de proteínase. }\end{array}$ & $\begin{array}{l}\text { Atua na regulação de } \\
\text { reações inflamatórias } \\
\text { e inibe a atividade } \\
\text { proteolítica da tripsina, } \\
\text { da plasmina e da } \\
\text { calicreína. Associado a } \\
\text { doença de Crohn, mas } \\
\text { não doença ulcerativa. }\end{array}$ & $\begin{array}{l}\text { Turkay; Kasapoglu, } \\
2010\end{array}$ \\
\hline $\begin{array}{l}\text { Lactoferrina } \\
\text { (LAF; } 80 \text { kDa) }\end{array}$ & Fecal & $\begin{array}{l}\text { LAF está presente nos } \\
\text { grânulos de neutrófilos } \\
\text { e tem atividade } \\
\text { antimicrobiana. }\end{array}$ & $\begin{array}{l}\text { Uma concentração } \\
\text { elevada é um } \\
\text { indicador de } \\
\text { inflamação do } \\
\text { intestino. }\end{array}$ & $\begin{array}{l}\text { Turkay; Kasapoglu } \\
\text { B, } 2010\end{array}$ \\
\hline $\begin{array}{l}\text { Calprotectina } \\
\text { (CAP; } \mathbf{3 6 . 5} \text { kDa) }\end{array}$ & $\begin{array}{l}\text { Fecal, plasma, } \\
\text { soro, urina }\end{array}$ & $\begin{array}{l}\text { CAP é uma proteína } \\
\text { ligadora de cálcio } \\
\text { e zinco da família } \\
\text { de proteínas } \\
\text { S100, formada } \\
\text { em granulócitos } \\
\text { neutrófilos (também } \\
\text { conhecida como MRP- } \\
8 / 14 \text {, calgranulina } \\
\text { A/B ou S100A8/A9). }\end{array}$ & $\begin{array}{l}\text { CAP é presente } \\
\text { no citoplasmática } \\
\text { de neutrófilos, } \\
\text { macrófagos e } \\
\text { eosinófilos do tecido } \\
\text { do íleal. Tem atividade } \\
\text { antimicrobiana, } \\
\text { imunomodulafdora } \\
\text { e efeitos } \\
\text { antiproliferativos. } \\
\text { É um potente } \\
\text { fator quimiotático } \\
\text { de neutrófilos }\end{array}$ & $\begin{array}{l}\text { Jun et al., } 2010 \\
\text { Turkay; Kasapoglu, } \\
2010\end{array}$ \\
\hline $\begin{array}{l}\text { Mieloperoxidase } \\
\text { (MPO; } 150 \text { kDa) }\end{array}$ & Fecal, urina & $\begin{array}{l}\text { MPO está presente } \\
\text { nos grânulos } \\
\text { de neutrófilos e } \\
\text { catalisa a oxidação } \\
\text { da substância } \\
\text { através H202. }\end{array}$ & $\begin{array}{l}\text { O sistema MPO } \\
\text { H2O2 tem um } \\
\text { efeito tóxico sobre } \\
\text { os microrganismos } \\
\text { e reflete a atividade } \\
\text { inflamatória no } \\
\text { intestino. }\end{array}$ & $\begin{array}{l}\text { Kosek et al., } 2013 \\
\text { Turkay; Kasapoglu, } \\
2010\end{array}$ \\
\hline $\begin{array}{l}\text { Neopterina } \\
\text { (NEP; } 253 \text { Da) }\end{array}$ & $\begin{array}{l}\text { Fecal, plasma, } \\
\text { soro, urina }\end{array}$ & $\begin{array}{l}\text { NEP é sintetizado } \\
\text { e liberado pela a } \\
\text { reação do sistema } \\
\text { imune celular de } \\
\text { macrófagos e de } \\
\text { células dendríticas } \\
\text { após estimulação } \\
\text { com IFN-g. }\end{array}$ & $\begin{array}{l}\text { NEP está associada } \\
\text { com a ativaç̦ão do } \\
\text { sistema imune celular }\end{array}$ & $\begin{array}{l}\text { Kosek et al., } 2013 \\
\text { Nancey et al., } 2013\end{array}$ \\
\hline
\end{tabular}




\begin{tabular}{|c|c|c|c|c|}
\hline Biomarcadores & Tipo de amostra & Função & Patobiologia & Referências \\
\hline $\begin{array}{l}\text { Elastase neutrofilica } \\
\text { (NE) }\end{array}$ & Fecal & $\begin{array}{l}\text { É uma proteinase } \\
\text { serina de grânulos } \\
\text { primários de leucócitos } \\
\text { polimorfonucleares os } \\
\text { quais são liberados } \\
\text { após ativacãão } \\
\text { neutrofilica. }\end{array}$ & $\begin{array}{l}\text { Elastase neutrofilica } \\
\text { pode solubilizar matrix } \\
\text { extracellular e é um } \\
\text { indicador de doenças } \\
\text { inflamatórias. }\end{array}$ & $\begin{array}{l}\text { Turkay; Kasapoglu, } \\
2010\end{array}$ \\
\hline \multicolumn{5}{|c|}{ Inflamação sistêmica e resposta imune } \\
\hline $\begin{array}{l}\text { Anti-citoplasma de } \\
\text { neutrófilos (ANCA) }\end{array}$ & Plasma & $\begin{array}{l}\text { São anticorpos } \\
\text { para grânulos de } \\
\text { neutrófilos. Associados } \\
\text { a pacientes com } \\
\text { doença ulcerativa, } \\
\text { mas não doença } \\
\text { de Crohn. }\end{array}$ & $\begin{array}{l}\text { Indica inflamação } \\
\text { crônica correlacionada } \\
\text { com aumento de } \\
\text { permeabilidade } \\
\text { intestinal. }\end{array}$ & $\begin{array}{l}\text { Turkay; Kasapoglu, } \\
2010\end{array}$ \\
\hline $\begin{array}{l}\text { Anticorpos anti- } \\
\text { Saccharomyces } \\
\text { (ASCA). }\end{array}$ & Plasma & $\begin{array}{l}\text { Homólogo à } \\
\text { parede celular de } \\
\text { enterobactérias } \\
\text { Associados a pacientes } \\
\text { com doença Crohn, } \\
\text { mas não doença } \\
\text { ulcerativa. }\end{array}$ & $\begin{array}{l}\text { Indica inflamação } \\
\text { crônica correlacionada } \\
\text { com aumento de } \\
\text { permeabilidade } \\
\text { intestinal }\end{array}$ & $\begin{array}{l}\text { Turkay; Kasapoglu, } \\
2010\end{array}$ \\
\hline $\begin{array}{l}\text { Proteína c-reactiva } \\
(\mathbf{P C R} ; \mathbf{1 2 5 . 5} \text { kDa) }\end{array}$ & Plasma, Soro & $\begin{array}{l}\text { PCR é uma } \\
\text { proteína de fase } \\
\text { aguda produzido } \\
\text { exclusivamente } \\
\text { no fígado após } \\
\text { estimulação pela } \\
\text { interleucina-6. }\end{array}$ & $\begin{array}{l}\text { PCR é um marcador } \\
\text { para a inflamaç̃õo } \\
\text { aguda e necrose do } \\
\text { tecido. A concentração } \\
\text { de PCR aumenta } \\
\text { dramaticamente após } \\
\text { infecçõ̃es microbianas. }\end{array}$ & $\begin{array}{l}\text { Turkay; Kasapoglu, } \\
2010\end{array}$ \\
\hline
\end{tabular}




\begin{tabular}{|c|c|c|c|c|}
\hline Biomarcadores & Tipo de amostra & Função & Patobiologia & Referências \\
\hline $\begin{array}{l}\text { Soro Amilóide A } \\
\text { (SAA-1; } \\
12.5 \text { kDa) }\end{array}$ & Plasma, Soro, Urina & $\begin{array}{l}0 \text { fígado é o } \\
\text { principal local de } \\
\text { síntese de SAA-1 } \\
\text { e é um reagente } \\
\text { de fase aguda. } \\
\text { SAA-1 tem funç̃es } \\
\text { imunomoduladoras } \\
\text { (quimiotaxia e } \\
\text { expressão de } \\
\text { moléculas de adesão), } \\
\text { propriedades de } \\
\text { citocinas e regulam } \\
\text { positivamente } \\
\text { metaloproteinases. } \\
\text { SAA-l é envolvido } \\
\text { no transporte e } \\
\text { metabolismo de } \\
\text { colesterol. }\end{array}$ & $\begin{array}{l}0 \text { aumento da } \\
\text { concentração de SAA-1 } \\
\text { é associada com a } \\
\text { inflamaçã̃o sistêmica. }\end{array}$ & $\begin{array}{l}\text { Reisinger et al., } 2014 \\
\text { de Villiers et al., } 2000\end{array}$ \\
\hline $\begin{array}{l}\text { Lipossacarídeo } \\
\text { (LPS; 20 KDa) }\end{array}$ & $\begin{array}{l}\text { Plasma, } \\
\text { Soro, Tecido } \\
\text { homogenado }\end{array}$ & $\begin{array}{l}\text { LPS é uma } \\
\text { endotoxina liberada } \\
\text { pelas bactérias. }\end{array}$ & $\begin{array}{l}0 \text { aumento de LPS } \\
\text { pode induzir efeitos } \\
\text { inflamatórios e } \\
\text { anti-coagulantes. }\end{array}$ & Wang et al., 2015 \\
\hline $\begin{array}{l}\text { Proteína de Ligação ao } \\
\text { LPS (LBP; } \mathbf{5 1} \mathbf{~ k D a )}\end{array}$ & Plasma, Soro & $\begin{array}{l}\text { LBP é uma proteína } \\
\text { de fase aguda que } \\
\text { é constituitivamente } \\
\text { produzida pelo fígado. } \\
\text { A proteína catalisa } \\
\text { a monomerização } \\
\text { do LPS e sua } \\
\text { transferência } \\
\text { para sCD14 e às } \\
\text { lipoproteínas. }\end{array}$ & $\begin{array}{l}\text { Esta proteína tem } \\
\text { ambos os papéis } \\
\text { na ativação de } \\
\text { monócitos por LPS } \\
\text { e na neutralizacção } \\
\text { dos LPS pela vía } \\
\text { da lipoproteína }\end{array}$ & $\begin{array}{l}\text { Brenchley et al., } 2011 \\
\text { Forsyth et al., } 2011\end{array}$ \\
\hline
\end{tabular}

*Abreviação: Da = daltons 


\subsection{TESTES E BIOMARCADORES ASSOCIADOS À ABSORCÃ̃O, PERMEABILIDADE, DANOS E REPARAÇÃO INTESTINAL}

Clinicamente, são utilizados métodos para a avaliação da permeabilidade intestinal. Destes, incluem os métodos clássicos de administrar aos pacientes substâncias que não metabolizadas, com tamanhos moleculares diferentes, a fim de verificar de forma especifica as rotas transcelular e paracelular do enterócito intestinal, além da verificação da integridade da mucosa gastrointestinal. Essas substâncias, geralmente, são administradas via oral e marcadas na urina. Dentre os principais marcadores, podemos citar carboidratos não metabolizáveis (manitol e lactulose), radioisótopos (p. ex. 51Cr-EDTA) e polietilenoglicol (PEG).

Frequentemente são utilizados na clínica e na pesquisa, e dentre estes temos como exemplo o teste do percentual de excreção de lactulose/manitol. Este teste consiste na administração de dose oral de uma solução contendo lactulose/manitol. O teste visa identificar a eliminação desses compostos na urina e, por não ser invasivo, é utilizado para avaliar a extensão da má absorção e comprometimento da permeabilidade intestinal. No ensaio, verifica-se a análise de dois carboidratos, o manitol, um monossacarídeo de peso molecular de $182 \mathrm{Da}$, o qual é transportado na célula intestinal através da via transcelular, enquanto outro carboidrato -a lactulose- um dissacarídeo de $342 \mathrm{Da}$, é transportado através do cruzamento das junções firmes localizadas nos espaços intercelulares consistentes na via paracelular da barreira intestinal. Utiliza-se para a detecção da taxa de excreção lactulose/ manitol a cromatografia líquida de alta eficiência, em inglês: High performance liquid chromatography, HPLC, esse método possui o detector amperométrico pulsato (HPLC-PAD) considerado vantajoso, fácil e sensível para medir a permeabilidade intestinal.

Em pacientes com doenças diarreicas, verificou-se um aumento da taxa de excreção de lactulose/manitol. Desta forma foi sugerido o comprometimento da integridade da mucosa intestinal, observado pelo elevado nível de lactulose urinário. Por outro lado, a função de absorção foi mantida nesses pacientes, já que não ocorreram alterações na medida da excreção de manitol (Figura 18.7).

A avaliação dos aspectos histopatológicos do dano ou a recuperação tecidual intestinal apresenta como uma importante técnica a histologia que visualiza a integridade das membranas, mediante coloração de hematoxilina e eosina e, possibilita detectar, em secções intestinais, doenças ulcerativas, como também inflamação intestinal grave, que podem acarretar no aumento da permeabilidade intestinal.

Em laboratórios, testes in vitro e in vivo estão implementando novas tecnologias com o intuito de proporcionar uma investigação mais minuciosa das estruturas histopatológicas, permitindo a constatação de alterações no tecido. No caso, a microscopia eletrônica é um importante método, em razão de que, essa permitiu a descoberta das junções firmes na barreira intestinal, possibilitando análise destas 
estruturas relacionadas com alterações na permeabilidade intestinal. Em adição, pesquisas têm utilizado métodos de coloração de imunofluorescência com aplicação de anticorpos específicos direcionados à visualização de várias proteínas de junções firmes na barreira gastrointestinal.

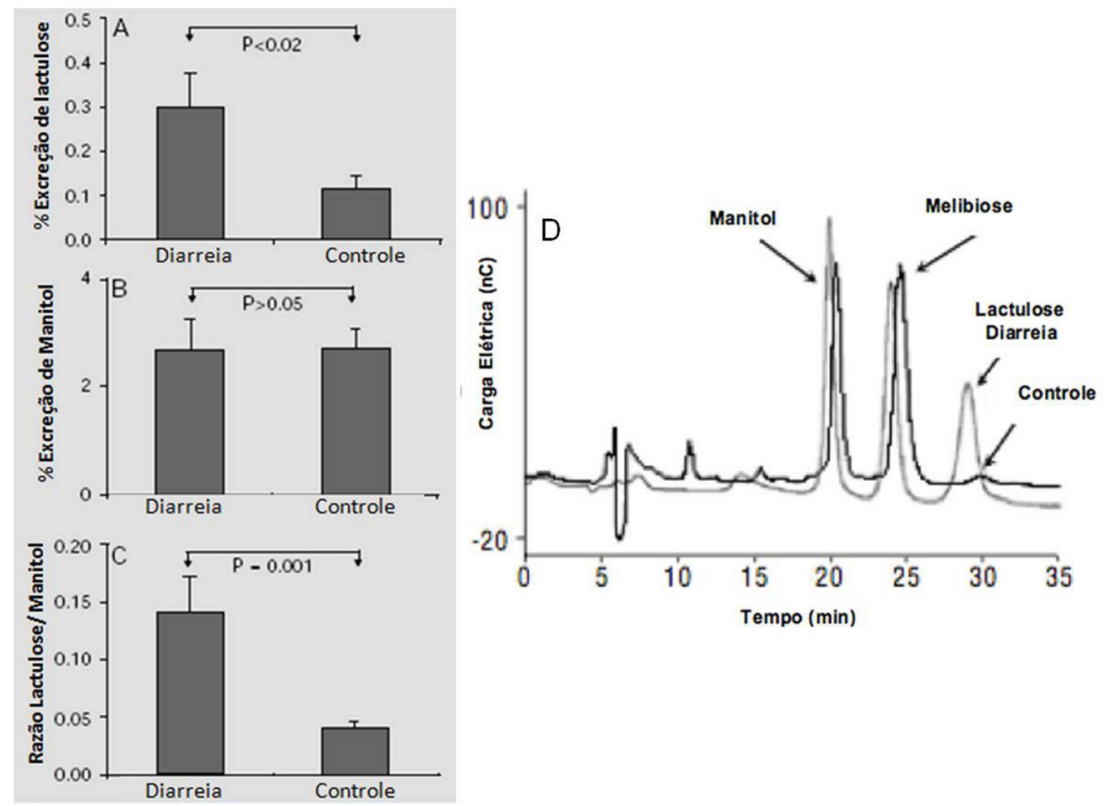

Figura 18.7 - Avaliação da permeabilidade intestinal pelo método de lactulose e de manitol. A) e B) apresenta a quantificação da lactoluse e manitol, respectivamente, em urina de crianças com e sem diarreia aguda $m$ apresenta. C) A razão entre lactulose/manitol no grupo avaliado. D) Cromatograma da quantificação dos carboidratos utilizados na avaliação da permeabilidade intestinal. Em ambos os cromatogramas apresentaram picos de melibiose como padrão interno na quantificação dos biomarcadores. 0 aumento de lactulose sugere alteraçōes na permeabilidade intestinal das crianças com diarreia em ralação a crianças sem a manifestação de diarreia. Reproduzido a partir de A.A.M Lima. Barbosa-Junior MS, Silva TMJ, Guerrant R, Lima AAM. Brazilian Journal of Medical and Biological Research. v. 32 p. 1499-1504, 1999.

Análises de proteômica e a transcrição de RNA das proteínas de junções firmes por meio, do western blot e da reação de polimerase, respectivamente, utilizado em estudos laboratoriais, indicam importantes marcadores de alterações na permeabilidade intestinal.

Além disso, as proteínas de ligação de ácidos graxos no íleo (I-FABPs) estão localizadas, exclusivamente, em enterócitos maduros do intestino delgado é liberado para a circulação logo quando ocorre o dano epitelial intestinal, podendo ser detectado na urina ou no plasma. Medições de concentrações I-FABP no plasma em animais laboratoriais e estudos clínicos mostraram que esse é um método altamente específico e sensível para avaliar a gravidade da lesão da mucosa intestinal. 
Em adição, a permeabilidade intestinal também pode ser avaliada pela detecção da zonulina, que é uma proteína das células intestinais localizada na zona de oclusão. Estudos laboratoriais demonstraram que a zonulina está associada ao desarranjo celular, promovendo o aumento da permeabilidade intestinal. $\mathrm{O}$ aumento de zonulina foi verificado em patologias clínicas como a doença celíaca.

A diamina oxidase (DAO) é a principal enzima para catalisar a oxidação de diaminas como a histamina, putrescina, cadaverina. A DAO apresenta expressão, de forma predominante na mucosa intestinal humana e pode ser encontrada no soro, esta tem a característica de correlacionar-se inversamente à permeabilidade intestinal. DAO é especificamente localizada na extremidade dos enterócitos das vilosidades, e sua atividade reflete a integridade e maturidade da mucosa do intestino delgado.

Em pesquisas clínicas com crianças desnutridas, verificou-se a associação com as proteínas de gene de regeneração 1 (Reg1) que estão envolvidas na reparação de tecidos, crescimento celular e regeneração epitelial. Entre as proteínas de Reg1, a proteína denominada litostatine-1-beta ou gene de regeneração -1-beta $(\operatorname{Reg} 1 \beta)$ foi indicada como um potencial marcador para lesão intestinal, bem como foi associada a desnutrição.

\subsection{BIOMARCADORES ENVOLVIDOS NA INFLAMAÇÃO SISTÊMICA E RESPOSTA IMUNE ASSOCIADOS A AVALIAC̣ÃO DE PERMEABILIDADE INTESTINAL E DOENÇAS ASSOCIADAS}

Marcadores biológicos são estudados nas inflamações intestinais, como parâmetro mensurável, que permitem conhecer o grau de severidade, capacidade de monitoramento do curso de uma doença ou de uma resposta a uma intervenção terapêutica.

O diagnóstico estabelecido das doenças inflamatórias intestinais envolve testes endoscópicos, radiológicos, patológicos, clínicos e laboratoriais no entanto, medidas indiretas pelos índices clínicos da atividade da doença não podem oferecer um prognóstico da atividade inflamatória encontrada pela via endoscopia e pelo exame histológico. A endoscopia é precisa, mas é invasiva e de alto custo.

Assim, é importante a investigação de biomarcadores com a vantagem da obtenção de testes simples, reprodutíveis, rápidos, não-invasivos e de relativamente baixo custo monetário, com potencial de diagnóstico de precisão e de acompanhamento do curso das doenças inflamatórias.

A abordagem clínica aponta uma grande variedade de biomarcadores relacionados com a inflamação, tal como a resposta imune. Estes marcadores são baseados em auto-anticorpos, sorológicos, detectados em fezes como também relacionados com a resposta imune e infecção. 
Biomarcadores auto-anticorpos são marcadores imunológicos, os quais são baseados na detecção de uma ampla variedade de anticorpos. Esses biomarcadores utilizam reações cruzadas, com numerosos antígenos de fungos e bactérias. Logo, os anticorpos no decorrer da doença inflamatória intestinal podem resultar numa resposta imune anômala do organismo entre o hospedeiro e a microbiota.

Estes marcadores são encontrados como diagnóstico de doenças inflamatórias intestinais que têm a capacidade de aumentar a permeabilidade intestinal. A combinação dos biomarcadores auto-anticorpos e fecais foram sugeridos para acompanhamento e identificação de pacientes que necessitam de testes invasivos.

Alguns biomarmarcadores já utilizados como diagnóstico estão correlacionados a uma doença de forma proeminente como anticorpo anticitoplasma de neutrófilo (pANCA), que são anticorpos para grânulos de neutrófilos associados, principalmente a pacientes com doenças ulcerativas (DU), em contraste com anticorpos anti-Saccharomyces (ASCA), que são anticorpos contra um polímero de manose da levedura, Saccharomyces, homólogo à parede celular de enterobactérias e, principalmente, existentes naqueles com a doença de Crohn (DC).

Outros biomarcadores como proteína C porina da membrana da Escherichia coli (OmpC), o anticorpo antissequência I2 associada a Pseudomonas flourescens (anti-I2), anticorpo antiflagelina (anti-cBir); anticorpo anti- carbohidrato laminaribiosido (ALCA) e anticorpo anti-carbohidrato citobiosido (ACCA) são encontradas as doenças inflamatórias intestinais, no entanto, não são utilizadas como ferramentas de diagnóstico e diferenciação de doenças.

Biomarcadores sorológicos são conhecidos por serem bons indicadores da atividade inflamatórias intestinais e extrainstetinal. $\mathrm{Na}$ abordagem clínica, incluem a proteína C-reativa (PCR) e soro amiloide A (SAA).

A PCR é considerada a proteína mais importante na inflamação aguda. Ademais, em indivíduos saudáveis, os hepatócipos secretam baixos níveis dessa proteína $(1 \mathrm{mg} / \mathrm{L})$. As citocinas (IL-6, TNF- $\alpha$ e IL-1 $\beta)$, associadas à inflamação aguda intestinal, podem aumentar rapidamente a PCR e, posteriormente, acarretam a sua diminuição acentuadamente; pois esta apresenta uma meia-vida de aproximadamente 19 horas. A PCR está mais proeminente associada à doença de Crohn do que às doenças ulcerativas.

A SAA é considerada proteína de fase aguda, que indica resposta inflamatória em processos infecciosos e não infecciosos. Estudos clínicos e em animais demonstram que níveis de SAA refletem a gravidade da doença de cólon.

Biomarcadores fecais compreendem um grupo bastante heterogêneo de substâncias e são importantes indicadores da inflamação intestinal, associados especificamente ao trato gastrointestinal.

A marcação de leucócitos radiomarcados, nas fezes, por meio do índio-111 é considerada o padrão de diagnóstico-ouro da inflamação com alta sensibilidade de diagnóstico nas doenças inflamatórias intestinais. Ademais, a técnica de radiomarcados nas fezes continua muito importante; contudo, não são recomendadas 
na rotina clínica em decorrência da exposição à radiação, ao elevado custo e à demora de quatro dias, em razão da coleta de fezes.

$\mathrm{Na}$ rotina clínica, são necessários testes rápidos, fáceis e, relativamente, de baixo custo; então foram criados outros ensaios. Alfa1-antitripsina fecal, que é um inibidor de protease produzida pelo fígado, epitélio intestinal e macrófagos, é um indicador de inflamação intestinal e é marcador útil para o aumento da permeabilidade da barreira intestinal durante a inflamação intestinal, sendo considerado um teste fácil, mas de alto custo.

$\mathrm{O}$ alfa2-macroglobulina, soro anti-proteinase, também apresenta uma relação positiva com a inflamação intestinal, principalmente, associado ao índice da atividade de doença de Crohn, mas não com a colite ulcerativa.

Os marcadores fecais oriundos de ativação neutrofílica têm emergido como ferramentas importantes ao diagnóstico de inflamação intestinal, provavelmente em razão da facilidade e relativamente baixo custo. Dentre os marcadores fecais, estão a mieloperoxidase, a calprotectina, a lactoferrina e a elastase neutrofílica. A lactoferrina e a calprotectina são liberadas ativamente pela mucosa inflamada durante a migração de ativação de neutrófilos, que pode estar correlacionada com o aumento de permeabilidade intestinal.

A lactoferrina consiste numa glicoproteína ligada aos íons de ferro e, é o maior componente dos grânulos secundários dos neutrofílos polimorfonucleares, sendo a lactoferrina significativamente aumentada na inflamação aguda no trato gastrointestinal. Apesar de a lactoferrina ser um marcador neutrofílico, células exócrinas também podem liberar quantidades inferiores dessa proteína, como também a lactoferrina está em muitos fluídos, como leite humano normal, lágrimas, fluido sinovial e soro. Estudos mostram que a lactoferrina e a calprotectina apresentam desempenho semelhante; todavia, apenas aquela se correlaciona bem com a proteína C-reativa na inflamação da mucosa diagnosticada por endoscopia.

A calprotectina é proteína ligada ao cálcio e ao zinco, que inibe metaloptoteinase, apresenta atividade antifúngica e induz a apoptose em cultura de células. É encontrada em monócitos e macrófagos e constitui cerca de 50-60\% do citoplasma neutrofílico. Diversos estudos mostram que esta proteína está associada à quantificação de neutrófilos na mucosa intestinal, como um indicador de condições inflamatórias, associada também a outros biomarcadores, o que é considerado um parâmetro de indicação de alteração da permeabilidade intestinal.

A mieloperoxidase (MPO) é um importante componente dos grânulos primários (azurofílos) e está em menores quantidades em monócitos e em macrófagos. A MPO é uma enzima que catalisa oxidação de hidrogênio, formando substâncias reativas, como o ácido hipocloroso, radicais tirosil e intermediários de nitrogênio. A MPO tem se mostrado um importante marcador no monitoramento de doenças inflamatórias intestinais.

Outro marcador é a neopterina, reconhecida como pertencente ao grupo das pterinas e é sintetizada por macrófagos, sendo considerada como um indicador da inflamação intestinal e da resposta imune celular. 
Marcadores como a elastase neutrofílica (NE) são liberados pela ativação de neutrófilos polimorfonucleares, associados à inflamação gastrointestinal.

Outros biomarcadores são associados ao grau de infecções que podem potencialmente refletir translocação bacteriana acarretada pelo aumento da permeabilidade da barreira funcional intestinal.

Para fins científicos e experimentais, metodologias mais refinadas são utilizadas para a identificação de bactérias e de padrões moleculares associados a patógenos (PMAPs), de forma indireta, tal como por meio da expressão gênica, p. ex a transcrição do RNA ribossômico $16 \mathrm{~S}$ ou do sequenciamento de rRNA $16 \mathrm{~S}$.

Alguns modelos in vivo em pesquisas utilizam a expressão marcadora com uma proteína verde fluorescente associada à transfecção plasmidial da Escherichia coli, é manipulada em uma suspensão de bactérias marcadas com fluorescência, e, esta é administrada no animal demonstrando que a disrupção da barreira intestinal pode promover a translocação de bactérias viáveis marcadas detectadas por meio da microscopia de fluorescência.

Avaliação de aspectos da resposta inflamatória desencadeada pelo lipopolissacarídeo (LPS), pela proteína de ligação ao LPS (LBP) e pela proteína de cluster de diferenciação 14 solúvel (sCD14) estão associadas à infecção, podem ser mensurados nos níveis séricos do plasma ou dos tecidos por imunoensaio enzimático (ELISA). Pesquisas em pacientes com doenças inflamatórias intestinais demonstraram aumento dos níveis séricos de LBP e sCD14 correlacionado com a atividade da doença, após tratamento, verificou-se recuperação dos parâmetros normais, menos para pacientes com Doença de Crohn.

\subsection{BIOMARCADORES DO FUTURO PARA AVALIAÇÃO DE PERMEABILIDADE INTESTINAL E DOENÇAS ASSOCIADAS}

A investigação e a experimentação de novos biomarcadores é uma área ativa da pesquisa. Atualmente, as plataformas tecnológicas podem ser utilizadas para estudar formas de diagnósticos de inflamação intestinal, como também de mensurar e investigar o grau de absorção, o dano e o reparo da barreira intestinal. Recentemente, passaram a existir estudos em Genética, proteômica e metabolômica sobre o tema.

Estudos em Genética mostram vários genes como candidatos para a avaliação da inflamação intestinal, incluindo a investigação de estudos genômicos (GWAS) ou de polimorfismo genéticos, como aqueles associados aos genes NOD2, IL23/17 e os genes codificadores da autofagia. Ademais, os pequenos RNA não-codificantes (miRNAs) podem apresentar expressão diferentes na mucosa intestinal alterada.

Estudos em Proteômica mostram avanços significativos na área de Biotecnologia com estudos em Proteômica Clássica, como também a subproteômica 
associadas aos fluídos, aos compartimentos celulares e às organelas, que podem estar associados à inflamação da mucosa intestinal e à medição de junções firmes. Pesquisas clínicas sugerem como potencial biomarcador a isoforma dimérica da piruvato quinase (M2-PK tumoral) que é localizada em tecidos com alta capacidade proliferativa. M2-PK foi detectado nas fezes de pacientes com cancro colorretal e outras doenças que podem aumentar a permeabilidade instestinal.

Estudos em metabolômica, com base em análises comparativas de grupos, permitem a abordagem do perfil metabólico para um entendimento mais profundo das alterações das vias metabólicas, bem como possibilitam a identificação de inúmeras substâncias com potencial para serem biomarcadoras. Pesquisa realizada por Mayneris-Perxachs e colaboradores detectou indoleamina 2,3-dioxigenase (IDO) é uma enzima que está presente em vários tecidos extra-hepáticos e a sua expressão é aumentada em resposta a infecção e inflamação. Essa reflete a inflamação sistêmica associada a um aumento da permeabilidade intestinal que é observado em crianças com desnutrição e infecção.

\section{REFERÊNCIAS BIBLIOGÁFICAS}

1. ANDERSON, J. M.; ITALLIE, C. M. V. Physiology and Function of the Tight Junction. Cold Spring Harbor Perspectives in Biology. 1: 1-16, 2009.

2. ITALLIE, C. V. W.; ANDERSON, J. M. American Physiological Society. 19: 331-338, 2004.

3. TAMURA, A.; TSUKITA, S. Paracellular barrier and channel functions of TJ claudins in organizing biological systems: Advances in the field of barriology revealed in knockout mice. Seminars in Cell \& Developmental Biology. 36: 177-185, 2014.

4. MARTíneZ, C.; GONZÁlEZ-CASTRO, A.; VICARIO, M.; SANTO, J. Cellular and Molecular Basis of Intestinal Barrier Dysfunction in the Irritable Bowel Syndrome. Gut and Liver. 305-315, 2012.

5. TUNER, J. R. Intestinal mucosal barrier function in health and disease. Nature Reviews Immunology. 9: 799-809, 2009.

6. RADTKE, F.; CLEVERS, H. Self-Renewal and Cancer of the Gut: Two Sides of a Coin. Science. 25: 1905-1908, 2005.

7. TAMURA, A.; TSUKITA, S. Paracellular barrier and channel functions of TJ claudins in organizing biological systems: Advances in the field of barriology revealed in knockout mice. Seminars in Cell \& Developmental Biology. 36: 177-185, 2014. 
8. SUZUKI, T. Regulation of intestinal epithelial permeability by tight junctions. Cellular and Molecular Life Sciences. 70: 631-659, 2013.

9. TAMURA, A.; HAYASHI, H.; IMASATO, M.; YAMAZAKI, Y.; HAGIWARA, A. ET AL. Loss of Claudin-15, but Not Claudin-2, Causes Na Deficiency and Glucose Malabsorption in Mouse Small Intestine. Gastroenterology. 140: 913-923, 2011.

10.WADA, M.;TAMURA,A.;TAKAHASHI, N.; TSUKITA, S. Loss of Claudins 2 and 15 From Mice Causes Defects in Paracellular $\mathrm{Na}^{+}$Flow and NutrientTransport in Gut and Leads to Death from Malnutrition. Gastroenterology. 144: 369$380,2013$.

11. ARRIETA, M. C.; BISTRITZ, L.; MEDDINGS, J. B. Alterations in Intestinal Permeability. Gut. 55: 1512-1520, 2006.

12. NATIVIDAD, J. M. M.; VERDU, E. F. Modulation of intestinal barrier by intestinal microbiota: Pathological and therapeutic implications. Pharmacological Research. 69: 42-51, 2013.

13. PETERSON, L. W.; ARTIS, D. Intestinal epithelial cells: regulators of barrier function and imune homeostasis. Nature Reviews Immunology. 14: 141153, 2014.

14. CARICILLI, A. M.; CASTOLDI, A.; CÂMARA, N. O. S. Intestinal barrier: A gentlemen's agreement between microbiota and immunity. World Journal of Gastrointestinal Pathophysiology. 5: 18-32, 2014.

15. KEITA, A. V.; SODERHOLM, J. D. The intestinal barrier and its regulation by neuroimmune factors. Neurogastroenterology \& Motiliy. 22: 718-733, 2010.

16. NATIVIDAD, J. M. M.; VERDU, E. F. Modulation of intestinal barrier by intestinal microbiota: Pathological and therapeutic implications. Pharmacological Research. 69: 42-51, 2013.

17. BARBOSA-JUNIOR, M. S.; SILVA, T. M. J.; GUERRANT, R.; LIMA, A. A. $M$. Measurement of intestinal permeability using mannitol and lactulose in children with diarrheal diseases. Brazilian Journal of Medical and Biological Research. 32: 1499-1504, 1999.

18. BRENCHLEY, J. M.; DOUEK, D. C. Microbial translocation across the GI tract. Annual Review of Immunology. 30: 149-73, 2012. 
19. CHEVALIER, M. F.; PETITJEAN, G.; DUNYACH-REMY, C.; DIDIER, C.; GIRARD, P. M. ET AL. The Th17/Treg ratio, IL-1RA and sCD14 levels in primary HIV infection predict the T-cell activation set point in the absence of systemic microbial translocation. PLoS Pathogens. 9: e1003453, 2013.

20. DE VILLIERS, W. J.; VARILEK, G. W.; DE BEER, F. C.; GUO, J. T.; KINDY, M. S. Increased serum amyloid a levels reflect colitis severity and precede amyloid formation in IL-2 knockout mice. Cytokine. 12: 1337-47, 2000.

21. FORSYTH, C. B.; SHANNON, K. M.; KORDOWER, J. H.; VOIGT, R. M.; SHAIKH, M. ET AL. Increased intestinal permeability correlates with sigmoid mucosa alpha-synuclein staining and endotoxin exposure markers in early Parkinson's disease. PloS One. 6: e28032, 2011.

22. ISKANDAR, H. N.; CIORBA, M. A. Biomarkers in inflammatory bowel disease: current practices and recent advances. Translational Research. 313$325,2012$.

23. JUNG, S. Y.; PARK, Y. B.; HA, Y. J.; LEE, K. H.; LEE, S. K. Serum calprotectin as a marker for disease activity and severity in adult-onset Still's disease. J. Rheumatol. 37: 1029-34, 2010.

24. MAYNERIS-PERXACHS, J.; LIMA, A. A.; GUERRANT, R. L.; LEITE, A. M.; MOURA. A. F. ET AL. Urinary N-methylnicotinamide and $\beta$-aminoisobutyric acid predict catch-up growth in undernourished Brazilian children. Sci. Rep. 6: 19780, 2016.

25. NANCEY, S.; BOSCHETTI, G.; MOUSSATA, D.; COTTE, E.; PEYRAS, J. ET $A L$. Neopterin is a novel reliable fecal marker as accurate as calprotectin for predicting endoscopic disease activity in patients with inflammatory bowel diseases. Inflammatory Bowel Diseases. 19: 1043-52, 2013.

26. PELSERS, M. M.; NAMIOT, Z.; KISIELEWSKI, W.; NAMIOT, A.; JANUSZKIEWICZ, M. ET AL. Intestinal-type and liver-type fatty acidbinding protein in the intestine. Tissue distribution and clinical utility. Clin. Biochem. 36: 529-35, 2003.

27. PETERSON, K. M.; BUSS, J.; EASLEY, R.; YANG, Z.; KORPE, P. S. ET AL. REG1B as a predictor of childhood stunting in Bangladesh and Peru. The American Journal of Clinical Nutrition. 9: 1129-33, 2013.

28. REISINGER, K. W.; KRAMER, B. W.; VAN DER ZEE, D. C.; BROUWERS, H. A.; BUURMAN, W. A. ET AL. Non-invasive serum amyloid A (SAA) measurement and plasma platelets for accurate prediction of surgical 
intervention in severe necrotizing enterocolitis (NEC). PLoS One. 9: 90834, 2014.

29. TURKAY, C.; KASAPOGLU, B. Noninvasive methods in evaluation of inflammatory bowel disease: where do we stand now? An update. Clinics. 65: 221-31, 2010.

30. WANG, L.; LLORENTE, C.; HARTMANN, P.; YANG, A.; CHEN, P.; SCHNABL, B. Methods to determine intestinal permeability and bacterial translocation during liver disease. Journal of Immunological Methods. 421: 44-53, 2015. 